PROTEIN AND CREATINE SUPPLEMENTATION HABITS AMONG UNIVERSITY STUDENTS (113 pp.)

\author{
Co-Directors of Thesis: Angie Ha, Ph.D. \\ Natalie Caine-Bish, Ph.D., R.D., L.D.
}

The purpose of this study was to conduct a descriptive analysis of protein and creatine supplementation habits among college students using a random sample at a public Midwestern state university. An electronic survey was sent to 8,000 randomly chosen students at the main campus of Kent State University (Ohio). Only 9.8\% (129 participants) of the sample size reported supplement use. Frequencies, t-tests, and chisquare tests were calculated in regards to supplementation habits, knowledge, and gender. Looking at the results, it was apparent that there was an inadequate amount of knowledge regarding protein and creatine supplementation in both genders. Significant gender differences were found in time of supplementation, supplementation form, reasons for supplementation and knowledge of supplement ingredients. No significant difference was found in the amount of protein supplemented. Increased awareness and education are needed to increase understanding for the proper use of both supplements in this population. In addition, it will also allow students to make the proper assessment on whether supplementation is actually necessary. 


\title{
PROTEIN AND CREATINE SUPPLEMENTATION HABITS AMONG UNIVERSITY STUDENTS
}

\author{
A thesis submitted to the \\ Kent State University College and Graduate School \\ of Education, Health, and Human Services \\ in partial fulfillment of the requirements \\ for the degree of Master of Science
}

by

Steve T.A. Bui

August 2008 
Thesis written by

Steve T.A. Bui

B.A., Kent State University, 2006

M.S., Kent State University, 2008

\begin{tabular}{ll} 
& $\begin{array}{l}\text { Approved by } \\
\text { Natalie Caine-Bish }\end{array}$ \\
\hline Angie Ha & Co-Director, Master's Thesis Committee \\
\hline Karen Lowry-Gordon & Member, Master's Thesis Committee \\
Accepted by & Director, School of Family and Consumer Studies \\
\hline Mary Dellmann-Jenkins & , Dean, College and Graduate School of Education, \\
\hline Daniel F. Mahony & Health, and Human Service
\end{tabular}




\section{ACKNOWLEDGEMENTS}

First off, I would like to thank all the members in my thesis committee: Dr. Natalie Caine-Bish, Dr. Angie Ha, and Dr. Karen Lowry. Without your help and dedication, this project would have never been possible. Special thanks to Dr. Angie Ha and Dr. Caine-Bish for being the most talented advisors, mentors, and teachers that I could ever hope for. Never have I ever felt the desire to succeed and learn so much except after attending one of your classes. You have helped me in many ways in the past two years, and have given me the inspiration and motivation to complete this project.

I would like to thank all my friends (in particular Armin, Noor, and Sunny) for being such great friends in the past five years. They have helped shape me into who I am today, and their friendship will always be valued. I would also like to thank Margaret for always being there for me, even the times when I have been incredibly stubborn and foolish. I can never say thank-you enough times.

Lastly I would like to thank my Mother. Even though she had no idea what a "Master's thesis" was, and had no idea what I have been doing the last two years of my life except "I've been going to school," she has supported and encouraged me to the fullest extent. 
ACKNOWLEDGEMENTS...................................................

LIST OF TABLES ........................................................... vi

CHAPTER

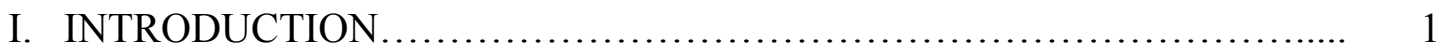

Problem Statement........................................... 3

Purpose Statement............................................... 4

Definition of Terms............................................ 4

Hypothesis................................................... 4

II. REVIEW OF LITERATURE........................................... 6

Supplement Definition and Regulation........................... 6

What Are Ergogenic Aids? ..................................... 7

Sales and Reasons for Nutritional Ergogenic Use..................... 9

Aerobic/Endurance and Anaerobic/Strength Exercise................ 10

Protein......................................................... 10

Amino Acids................................................ 16

Essential Amino Acids................................... 17

Conditionally Essential Amino Acids....................... 25

Non-Essential Amino Acids.................................. 29

Creatine........................................................ 33

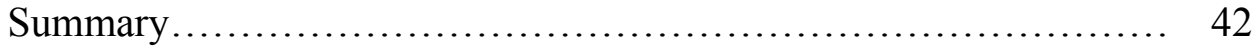

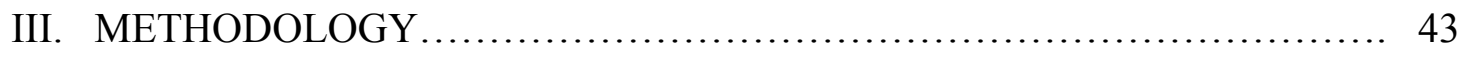

Research Design................................................ 43

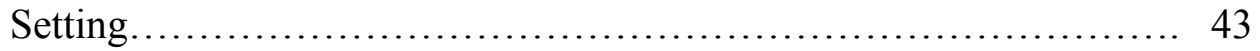

Subjects............................................................. 43

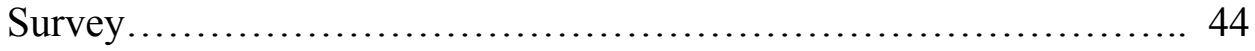

Survey Administration............................................ 46

Analysis....................................................... 46

IV. JOURNAL ARTICLE .................................................. 48

Introduction..................................................... 48

Methods....................................................... 50

Research Design......................................... 50

Subjects................................................... 51

Survey ................................................... 51

Survey Administration........................................ 53 


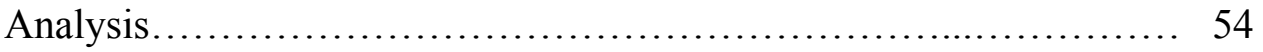

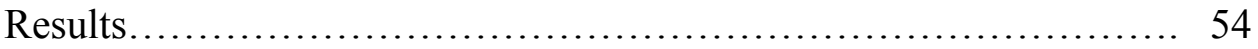

Creatine-Users......................................... 60

Protein-Users................................................. 60

Open-Ended Answers.................................. 71

Discussion........................................................... 73

Creatine Use.................................................... 73

Protein Use............................................... 76

Applications.............................................. 80

Limitations............................................... 82

Conclusion....................................................... 83

APPENDIX

Consent Form................................................... 85

Protein and Creatine Supplementation Habits Among University

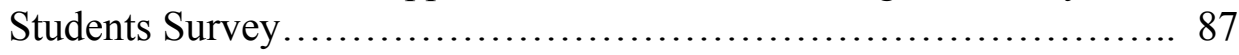

REFERENCES......................................................... 93 


\section{LIST OF TABLES}

Table

Page

1. Demographic Information of Non-Supplement Users..................... 56

2. Demographic Information of Supplement Users........................ 58

3. Creatine Supplementation Habits.................................... 62

4. Protein Supplementation Habits....................................... 64

5. Comparison of Male and Female Supplementation Users.................... 66

6. Comparison of Male and Female Protein Intake......................... 70

7. Open Ended Answers............................................. 72 


\section{CHAPTER I}

\section{INTRODUCTION}

The popularity of the supplement industry has gradually been increasing in the past few decades. It was reported that as many as half of the adults in the United States used supplements and in 1996 more than $\$ 6.5$ billion was being spent annually on dietary supplements (Kurtzweil 1998). Furthermore, dietary supplement sales have increased from $\$ 8.8$ billion in 1994 to $\$ 15.7$ billion in 2000 (Blendon et al. 2001). The National Health and Nutrition Examination Survey (NHANES) has reported that approximately $52 \%$ of all Americans are taking some form of a supplement, and studies have shown that more than $59 \%$ of the general population use them on a daily basis (Radimer et al. 2004; Archer et al. 2005). Many times the supplements being taken are classified as an ergogenic aid: any substance, food, chemical, or practice that may improve energy, performance, or recovery (McKinley Health Center 2007, University of Iowa Hospitals \& Clinics 2007).

In 1999, Americans spent $\$ 1.4$ billion on ergogenic aids and 1.2 million people reported using them regularly (Bovill et al. 2003). A large subpopulation of these consumers is college students. A survey conducted by Newberry (2001) found that $48.5 \%$ of all undergraduate students were using some form of non-vitamin or non-mineral supplement. Supplementation is even more prevalent in competitive college athletics. Some surveys have shown that approximately $75 \%$ of the college athletes take supplements (McKinley Health Center 2007). Other studies have shown anywhere from 
40 to $79 \%$ of all college athletes take supplements in hopes of improving performance (Froiland 2004; Stephens 2001).

The majority of dietary supplements do little to enhance performance, and many substances market claims that are unsupported by well-controlled research; yet athletes and other physically active individuals will still continue to make use of them (Jeukendrup and Gleeson 2004; Sheepard et al. 2000). In a study by Haymes (1991), it has been reported that athletes will sometimes continue to take ergogenic aids despite the fact that the nutrition community has shown that the supplement in question has no effect on performance. In a study investigating dietary supplement use in varsity athletes, it was reported that $46 \%$ of all those who completed the survey felt they did not know enough about supplements, $16 \%$ reported they were not sure whether they knew enough about supplements, and $37 \%$ of participants reported that would like to learn more about supplements (Kristiansen et al. 2005).

There have been many studies that involve vitamin, mineral, herbal, macronutrient, and micronutrient supplements; however, there seems to be a lack of studies that report supplement use and practices of protein and creatine (two of the most popular performance enhancing supplements) in a normal population (Nemet \& Eliakim 2007, Metzl et al. 2001; Strauss 1998). In past studies concerning protein and creatine, there seems to be a high level of misunderstanding involving the proper purpose, use, and dosage regarding the supplements. Often supplements will be taken in higher than normal doses. For example, in Lemon et al.'s 1992 study, when questioning a bodybuilder or some type of strength training athlete, a common belief was to take of $2.0-4.0 \mathrm{~g} / \mathrm{kg}$ of 
protein per day to maximize results. In another study, $65 \%$ of protein supplement users believed that protein is the body's energy source during short-term athletic events (Bovill et al. 2003).

Misconceptions with creatine use are equally prevalent. In a study involving 52 athletes, 39 exceeded the recommended maintenance dosage of creatine per day. Eighteen of those 39 athletes took more than $3 \mathrm{~g} / \mathrm{day}$, another 18 took over $9 \mathrm{~g} / \mathrm{day}$, and three of the players took 17-20 g/day when the most efficient amount documented is only 2 g/day (Juhn et al. 1999). In another study, 674 athletes were surveyed and more than $40 \%$ of the sample used an incorrect loading method for creatine. Additionally, $70 \%$ took excessive amounts of creatine for the maintenance phase (Ray et al. 2001).

\section{Problem Statement}

The percentage of supplement users in college NCAA athletes and the typical college undergraduate population has been reported anywhere from $40 \%$ upwards to $79 \%$ (Froiland 2004; Stephens 2001). Current and past studies regarding supplementation have covered a broad category of supplements including vitamin, mineral, herbal, macronutrient, and micronutrient supplements; however, there have been few studies that focus predominantly on two of the most popular performance enhancing supplements: protein and creatine (Nemet \& Eliakim 2007; Metzl et al. 2001; Strauss 1998). Even though both supplements have been available for decades, and are two of the most frequently used supplements, there still appears to be a high number of misinformed consumers regarding proper supplementation techniques. Since there is an abundant amount of information documenting the proper usage for both supplements, it is 
concerning to see the large number of individuals who still lack the knowledge to use

them correctly. College students and college athletes make up a portion of these protein and creatine users, yet there are few studies and little information documenting their protein and creatine supplementation habits. Further research is needed to determine the supplementation practices in college in hopes of educating the misinformed individuals.

\section{Purpose}

The purpose of this study is to conduct a descriptive analysis of protein and creatine supplementation habits among college students (including National Collegiate Athletic Association student athletes) using a random sample at a public Midwestern state university.

\section{Hypothesis}

It is hypothesized that there will be a significance difference in supplemental knowledge and reasons for use depending on gender.

\section{Definition of Terms}

- College Student: A Kent State University student who is: (1) not a parent, (2) currently enrolled in six or more credit hour per semester, (3) must be an undergraduate (4) may be an NCAA athlete.

- Dietary Supplement: any product that contains a "dietary ingredient" which can be taken orally, and is intended to complement the diet (Food and Drug Administration 2007). 
- Ergogenic Aid: any substance, food, chemical, or practice that may improve energy, performance, or recovery (McKinley Health Center 2007, University of Iowa Hospitals \& Clinics 2007).

- Aerobic/Endurance Exercise: any activity that is maintained continuously and uses and increases the body's need of oxygen. Should cause heart rate to reach 55 to $90 \%$ of maximum and should be maintained anywhere from 20 to 60 minutes.

- Anaerobic/Strength Exercise: exercise that builds muscles through tension and uses phospho-creatine and anaerobic glycolysis as the main sources of energy. 


\section{CHAPTER II}

\section{LITERATURE REVIEW}

\section{Supplement Definition and Regulation}

Until the previous decade, the term dietary supplement was extensive in meaning. In 1994, Congress defined the term, through the Dietary Supplement Health and Education Act (DSHEA), as a product that contains a "dietary ingredient" which can be taken orally, and is intended to complement the diet (Food and Drug Administration 2007b). Dietary ingredients that Congress included in the Act were: vitamins, minerals, herbs, botanicals, amino acids, enzymes, organ tissues. Furthermore, these substances could be marketed in several different forms such as tablets, capsules, soft-gels, gel-caps, liquids, bars, or powders.

In addition to the new definition of dietary supplement, the DSHEA changed the classification of supplements from a food to an exclusive sub-category of food. Under this new category, a brand new structure for safety testing and labeling of dietary supplements was instilled (Food and Drug Administration 2007a). All supplements were now required to bear ingredient labeling. Mandatory information included: name, quantity of each dietary ingredient, and total quantity of all dietary ingredients. Furthermore, the product must be labeled a supplement (Food and Drug Administration 2007a).

Claims that were prohibited included those that would diagnose, prevent, mitigate, treat, or cure a specific disease. Manufacturers were allowed to describe the supplement's positive effects as long as the claim was not misleading, and there was 
significant data supporting the claim (Food and Drug Administration 2007a). It also had to include a warning sign: "This statement has not been evaluated by the Food and Drug Administration" (Food and Drug Administration 2007a).

Under the DSHEA, the manufacturer was solely responsible for determining whether or not its supplements were safe, and whether any of its claims were true. Manufacturers did not have to provide the Food and Drug Administration (FDA) with any evidence demonstrating that its supplement was safe or effective. Additionally, the FDA did not require manufacturers to register their product; however, in 2003, the FDA released a rule that regulates current manufacturing practice requirements (Food and Drug Administration 2007a). They also initiated a process to create a systematic and predictable system in which supplements could be evaluated.

Currently there is an ongoing rise in dietary supplement use. In the United States alone, there has been an increase in sales from $\$ 8.8$ billion in 1994 to $\$ 15.7$ billion in 2000 (Blendon et al. 2001). In a research study conducted by Edmonds (2004), it was reported that $85 \%$ of the general population has used a supplement in the last year, and more than $59 \%$ use them on a daily basis.

\section{What Are Ergogenic Aids?}

Within the large category of dietary supplements there are ergogenic aids. The difference between an ergogenic aid and a dietary supplement is that an ergogenic aid is any substance, food, chemical, or practice that may improve energy, performance, or recovery (McKinley Health Center 2007, University of Iowa Hospitals \& Clinics 2007). Ergogenic aids can be classified into three categories: nutritional, pharmacological, and 
physiological. Nutritional ergogenic aids are nutrients acquired from food that may improve performance. Having the proper amount of nutrients allows for the body to control the three basic functions including: adequate energy source, regulation of energy, and tissue growth and development. Pharmacological ergogenics pertain to drugs that are intended to imitate hormones or neurotransmitters found in the human body (Williams 1998). An example would be amphetamines which cause an adrenaline response.

Pharmacological ergogenics have sparked the most debate and concern since they include steroids and many other illegal substances. The final category is physiological ergogenics. These substances may enhance natural physiological processes that produce physical power and energy in the body. Many of these supplements, such as creatine and carnitine, are combined with nutritional ergogenics since they can be ingested from food (Williams 1998).

The most popularly recognized ergogenic substances are administered orally by the means of pills, powders, or liquids (McKinley Health Center 2007). Since ergogenic aids consumed orally are classified as a supplement, they are regulated by the same methods as an ordinary dietary supplement. The FDA alone has to bring forth evidence showing that the supplement is dangerous for it to be recalled (Food and Drug Administration 2007a). The FDA can obtain information from inspections, manufacturers, and distributors along with having the ability to investigate any trade complaint or any adverse events associated with the use of a specific supplement. The majority of FDA resources are invested into public health emergencies and products that may cause injury or illness. The second priority of the FDA is to investigate products that 
are thought to be unsafe or fraudulent. The use of the remaining funds is for routine monitoring and any other types of recalls (Food and Drug Administration 2007a).

Sales and Reasons for Nutritional Ergogenic Use

Similar to dietary supplements, ergogenic supplements are an ever increasing industry. In 1999, Americans spend \$1.4 billion on ergogenic aids and 1.2 million people reported using them regularly (Bovill et al. 2003). Some studies have shown that anywhere from 40 to 79 percent of all college athletes take supplements in hopes of improving performance (Froiland 2004; Stephens 2001). One study involving bodybuilders recorded that $100 \%$ of the bodybuilders took supplements in hopes of improving performance (Burke \& Read 1993). National surveys have shown that manufacturers target young athletes as the primary market for their unregulated sports supplements (Healthy Competition 2002).

The most common reasons for using ergogenic aids include: enhanced performance, increased energy, or weight and muscle gains (Froiland 2004, Kruskall and Johnson (2001), Sobal and Marquart (1994). Information received by young athletes dealing with effectiveness is generally from promotional campaigns by the manufacturers, anecdotal evidence, or simply word of mouth (Froiland 2004). Other commonly used sources of information are family members (32.4\%), and fellow athletes $(31.9 \%)$. Information received from dietitians $(28.5 \%)$, coaches $(28.0 \%)$, trainers $(30.0 \%)$ or physicians $(<10 \%)$ are on a lower scale (Krumback et al. 1999; Kruskall and Johnson 2001). In a study by Jacobson and Gemmell (1991), it was reported that magazines were the primary source of knowledge for consumers dealing with supplements. 


\section{Aerobic/Endurance and Anaerobic/Strength Exercise}

Due to the varying requirements of the different forms of exercise, it is important to define what aerobic (endurance) exercise is compared to anaerobic (strength) exercise. The American College of Sports Medicine (ACSM) defines aerobic exercise as "any activity that uses large muscle groups that can be maintained continuously, and is rhythmic in nature (Doyle 1998)." It can also be described as exercise that increases the body's need for oxygen (Doyle 1998). Examples of good aerobic exercises include: walking, jogging, running, dancing, skiing, rollerblading, bicycling, swimming, rowing, stair climbing, and aerobics classes (Spark People 2007a). Aerobic exercise should also be at an intensity that allows the heart rate to reach 55 to $90 \%$ of maximum, and should be maintained anywhere from 20 to 60 minutes. Another way to measure proper intensity is to have a maximum oxygen uptake reserve at 40 to $85 \%$ (Morey 1999). In contrast to aerobic exercise, anaerobic is short lasting and high in intensity. Anaerobic exercise uses energy already stored in the muscles and does not depend on oxygen. According to ACSM, anaerobic strength training can be defined as "exercise that builds muscles through tension." Examples of anaerobic exercise include: weightlifting, sprints, running, biking, jumping rope, hill climbing, intervals, isometrics, or any type of hard exercise that is short and quick in manner (Spark People 2007b).

\section{Protein}

Protein is possibly the most marketed supplement used today (Nemet \& Eliakim 2007). It is an essential nutrient that is commonly found in the majority of foods, and has several important functions in the body. Bodily protein is constantly being synthesized or 
degraded to fit rapidly changing cellular needs (Tarnopolsky 2004). It assists in the development, repair, and growth of body tissues, and is required for muscle anabolism. This is especially important for athletes since protein is the building block for muscle during training. It also helps in metabolism regulation, and can be used as a secondary source of energy during exercise (Lemon 1998, Tarnopolsky 2004).

Currently, the recommended dietary allowance (RDA) for protein is 0.8 grams per kilogram (g/kg) of body weight for adults (Williams 1998). This amount includes both dietary and supplemented protein. It is widely accepted that athletes have a higher protein requirement than the RDA. Studies have shown that it ranges from 1.2-1.8 grams per kilogram per day (g/kg/d) for athletes (Lemon 1998, Lemon 2000, Tarnopolsky et al 1992, Lemon et al 1992). Again this includes both dietary and supplemented protein. During prolonged endurance type exercise, there is an increased oxidation of amino acids due to the lack of glycogen. Through different processes (depending on the specific amino acid) they can enter the Krebs cycle as pyruvate, acetyl-CoA, alphaketogluterate, succinyl-CoA, fumarate, or oxaloacetate aiding in the production of energy (Driskell 2000). Furthermore, the body releases higher levels of epinephrine and norepinephrine, and decreases insulin during extended endurance exercise. All of these reactions cause an increase in protein breakdown. Following endurance exercise, protein synthesis increases due to the muscle damage that has occurred. All of these actions cause endurance athletes to require about $1.2-1.4 \mathrm{~g} / \mathrm{kg} / \mathrm{d}$ of total (diet and supplemented combined) protein (Lemon 1998). 
Strength exercise is quite different from endurance exercise since increased amino acid oxidation does not occur at a significant level. During strength exercise, amino acids are not the main contributor of fuel. On the contrary, strength exercise minimizes the use of amino acids and maximizes the use of carbohydrates. The reason why there is still an increased protein need is due to the muscle hypertrophy that occurs as a result of muscle breakdown attributable to the strain of strength training. This causes strength training individuals to require an intake of $1.4-1.7 \mathrm{~g} / \mathrm{kg} / \mathrm{d}$ of total protein (Lemon 1998).

Absorption and digestion of protein begins immediately after ingestion in the stomach by peptidases. Peptidases hydrolyze peptide bonds leaving only free amino acids and some dipeptides and tripeptides (Driskell 2000). Now simply peptide fragments, they are moved into the small intestine where leftover peptide bonds are cut by trypsin, chymotrypsin, and elastase (Berdanier 2000). The fragments are then mixed with pancreatic juice and absorbed through the brush borders of the absorptive cells. During absorption, amino acids are transported by an active carrier system using a sodiumpotassium pump (Berdanier 2000). Once absorbed, they are moved to the liver by the hepatic portal vein. In the liver, the protein and nutrients are filtered, converted, and processed. They are then released into systematic circulation and delivered to where they are needed in the body (Jeukendrup and Gleeson 2004).

There are several other variables to consider when it comes to required protein intake. One of them is carbohydrate availability. During prolonged exercise when glycogen levels have been depleted, protein may contribute up to $15 \%$ of the energy used. However, it has been shown that when glycogen levels are high, only about $5 \%$ of the 
energy used comes from protein (Williams 1999). Having a diet low in carbohydrates can also lead to this depleted state of glycogen levels. Therefore, eating a moderate to highcarbohydrate diet can cause a protein-sparing effect by maintaining glycogen levels during exercise (Lemon 1998).

Another common trend is "more is better." Many athletes will have protein intakes higher than what is recommended. There has been minimal evidence to support the notion that an intake of greater than $1.7 \mathrm{~g} / \mathrm{kg} /$ day of total protein would provide additional muscle synthesis (Lemon 2000, Lemon et al 1992). In a study conducted by Tarnopolsky (1992), it was reported that an intake of $2.4 \mathrm{~g} / \mathrm{kg} /$ day of total protein did not increase protein synthesis any more than an intake of $1.4 \mathrm{~g} / \mathrm{kg}$ /day of total prtoein. However, the increase in protein led to an increase in amino acid oxidation. This means that the extra dietary protein is being used as energy rather than muscle synthesis. Using protein instead of carbohydrates for energy is inefficient and wasteful; therefore, serves no real advantage (Bahrke \& Yesalis 2002).

Although there is an increased need for athletes, most often a proper diet will allow athletes to obtain those requirements without supplements. The average American (non-athlete) consumes (without supplementation) about 100 grams of protein per day (Bahrke \& Yesalis 2002). If an athlete wanted to meet the $1.2-1.7 \mathrm{~g} / \mathrm{kg}$, they only need to consume approximately $12-20 \%$ of their calories as protein (Williams 1999).

It is important to understand that there is an inverse relationship between energy intake and protein need. Many times athletes do not consume enough calories to meet their energy needs due to a number of reasons: an example would be wrestlers trying to 
meet a certain weight class (Lemon 1998). During times when the body is deprived of energy from carbohydrates and fat, it obtains it from protein. Therefore, a decrease in energy intake would further increase an athlete's protein requirement since additional protein will be used as energy rather than muscle growth or repair (Lemon 1998).

When acquiring protein through food, it is important to evaluate protein quality. The essential amino acid content of foods determines the protein quality level in foods (Driskell 2000). Complete proteins are high quality proteins that contain all the essential amino acids required by the body. Generally, proteins acquired from animal-derived foods are complete. These can include: meat, poultry, fish, dairy products, and eggs (Driskell 2000). Approximately an ounce of any of the previous products contains about seven grams of protein, all essential amino acids. Nuts and legumes are also excellent sources (Bahrke \& Yesalis 2002). Incomplete proteins do not contain all the essential amino acids required by the body. It may not have all the essential amino acids, or there may be an inadequate amount found in the food. Most plant proteins are incomplete. Corn is an example due to its low levels of lysine (Wildman \& Medeiros 1999). Food sources can have complementary proteins. These are two or more food sources that have incomplete proteins; however, when combined together, they contain all the essential amino acids (Driskell 2000).

Time of protein ingestion plays a large role in maximal synthesis efficiency. In reported studies, it was shown that approximately an hour after exercise, muscle glycogen synthetic rate is the highest during the entire day (Ivy et al. 1988, Rasmussen 2000, Lemon 2000). This means it would be most beneficial to ingest protein during this time. 
It would also be beneficial to combine protein ingestion with a carbohydrate mixture. This is due to the fact that carbohydrates can cause an insulin release which stimulates amino acid uptake by the muscle and increased protein synthesis rates (Rasmussen et al. 2000, Van Loon et al. 2000, Roy et al. 1997). Additionally, it has been shown that resting levels of testosterone in the body were the highest when the protein to carbohydrate intake ratio was 1:4 (Volek et al. 1996).

Since the majority of protein anabolism occurs post-exercise, it would not be beneficial to ingest protein during or pre-exercise. During exercise, protein is not recommended since it is a secondary source of energy (it has to be converted through several steps before being released as energy). Converting protein to energy is not energy efficient, and it would be more effective to ingest small amounts of carbohydrates instead (Bahrke \& Yesalis 2002). Carbohydrates are more easily digested and converted to energy during exercise. High protein pre-exercise would likewise be non-beneficial since it elevates resting metabolism, causes dehydration, and would provide a slower source of energy when compared to carbohydrates (Powers 2006).

There are several noted potential negative effects of high protein intake. One of the biggest claims to date is impaired kidney function. It is not recommended for people with previous history of impaired kidney function to consume large amounts $(>2.0$ $\mathrm{g} / \mathrm{kg} / \mathrm{d}$ ) of protein since excess protein can cause an increase in kidney function due to the increased nitrogen excretion (Lemon 1998). It should be noted; however, that the kidneys are capable of this increase in workload, and in bodybuilders with extremely high protein intake (500-775\% of RDA) there has been no documented evidence of kidney problems 
(Lemon 1998). In experiments dealing with rodents ingesting a high protein intake diet ( $80 \%$ of total energy intake), the rodents were shown to have no real serious problems as well (Zaragoza et al. 1987).

High-protein diets can also cause an increase in urinary calcium loss. In women, it should be noted that this loss of calcium can increase the risk of osteoporosis (Lemon 1998). More research needs to be conducted in this area because observed calcium loss was generally seen only from ingesting protein supplements and not from ingesting protein acquired from foods (Lemon 1998). This increase in calcium loss can be counterbalanced by increasing phosphate consumption, which is abundant in most foods (Kohlmeier 2003; Lemon 1998).

Another common claim is that athletes with high protein intake have increased loss of fluids causing dehydration (Lemon 1998). When nitrogen is removed from the kidneys, it causes an increase in water loss via the kidneys as well. This should be carefully monitored in athletes who have greater fluid needs due to sweat loss, and since dehydration can adversely affect exercise performance it should be addressed properly. In measurements of some individuals consuming $2.0-2.6 \mathrm{~g} / \mathrm{kg} /$ day of protein, there has been a four-to-five time increase in urinary output (Lemon 1998). This increase in urinary output can easily be compensated by increasing water intake to match losses.

\section{Amino Acids}

Proteins are made from amino acids. Amino acids consist of an amino group, a carboxylic group, and a radical group connected by peptide bonds (Tarnopolsky 2004). The amino group and the carboxylic group are found in every amino acid. Each amino 
acid; however, has a unique radical group which determines its function and name. All protein ingested can be broken down into twenty different amino acids. They are then absorbed by the bloodstream, transferred to the liver where it is metabolized, and finally transported again via the blood to individual cells depending on function and need (Williams 1998).

There are three classifications for amino acids: essential, conditionally essential, and nonessential. Essential amino acids must be supplied through the diet since the body cannot produce them (Di Pasquale 1997). The nine essential amino acids include: histidine, isoleucine, leucine, lysine, methionine, phenylalanine, threonine, tryptophan, and valine (Tarnopolsky 2004; Driskell 2000; Food and Nutrition Board 2005). Conditionally essential amino acids are amino acids that need to be obtained through diet since the body cannot synthesize them in certain situations (Food and Nutrition Board 2005). Arginine, proline, and glycine are conditionally essential for low-birth-weight infants, and tyrosine and cysteine can sometimes not be synthesized due to low phenylalanine and methionine intake (Driskell 2000; Food and Nutrition Board 2005). The final category is nonessential amino acids. These can be synthesized by the body from other amino acids. They make up the last five amino acids: alanine, asparagine, aspartate, glutamate, and serine (Driskell 2000; Food and Nutrition Board 2005).

\section{Essential Amino Acids}

Histidine is an essential amino acid in adults. All basic dietary proteins contain histidine; however, pork and beef contain the highest amounts (Kohlmeier 2003). It is recommended that adults obtain $11 \mathrm{mg} / \mathrm{kg} / \mathrm{d}$ for proper function (Food and Nutrition 
Board 2005). Histidine is known to be a precursor and moderator of histamine production, and is an important component of hemoglobin (Food and Nutrition Board 2005). Histamine is produced by the removal of the carboxyl group from histidine by the enzyme histidine decarboxylase (Di Pasquale 1997). Histamine is involved in inflammatory responses and stimulates the release of hydrochloric acid in the stomach when eating (Di Pasquale 1997). Histidine can also be produced in the body from increased muscle protein breakdown resulting in 3-methyl histidine (Springboard 2004). Currently, there is not enough research involving histidine supplementation in regards to sports performance; therefore, recommendations cannot be made (Food and Nutrition Board 2005).

Isoleucine, as well as leucine and valine, makes up about $70 \%$ of all the amino acids in the body. All three amino acids are classified as branched chain amino acids (BCAA). Isoleucine can be acquired from majority of foods. Protein from dairy generally contains a higher level of isoleucine than those from meats and grains (Kohlmeier 2003). Adults are recommended to have at least $15-23 \mathrm{mg} / \mathrm{kg} / \mathrm{d}$ (Kohlmeier 2003, Food and Nutrition Board 2005). Isoleucine, in the proper dosage, has been shown to prevent muscle wasting and promote tissue repair after surgery or trauma. Some studies have shown that it stimulates the anabolic functions in humans. Isoleucine can also be converted into blood sugar (glucose) in the liver and; therefore, can act as a regulator for proper blood glucose levels. This gluconeogenic activity allows isoleucine to have a muscle-sparing capability (Springboard 2004). 
Leucine also belongs in the family of BCAA. All food proteins contain leucine; however, much like isoleucine, protein derived from dairy products contains slightly higher amounts. The recommended amount of leucine is approximately $34-40 \mathrm{mg} / \mathrm{kg} / \mathrm{d}$ or more (Kohlmeier 2003; Food and Nutrition Board 2005). During bouts of starvation, stress, infection, or recovery from trauma, leucine is used as a source of gluconeogenesis to assist in the healing. It has also been noted that since gluconeogenesis does occur when the body is under stress and starvation, leucine may actually aid in the prevention of protein and muscle wasting since it is easily broken down and converted to glucose (Kohlmeier 2003).

Valine is another amino acid belonging to the family of BCAA. Food sources with the largest concentration of valine are milk, eggs, and rice (Kohlmeier 2003). Valine participates in the detoxification of ammonia. Additionally, it is an important amino acid in the prevention of muscle wasting in diabetes patients. Along with leucine and isoleucine, it can be very helpful in preventing muscle breakdown by supplying it with extra glucose during intense exercise. It is recommended for adults to obtain 19-20 $\mathrm{mg} / \mathrm{kg} / \mathrm{d}$, a dose that is easily obtained by proper diet (Kohlmeier 2003; Food and Nutrition Board 2005). Too much valine in the diet can disrupt kidney and liver functions causing an increase in ammonia (Kohlmeier 2003).

The three BCAA, isoleucine, leucine, and valine, are popular as supplements due to the belief that they can reduce fatigue and protein breakdown (Jeukendrup and Gleeson 2004). It has been shown that increased brain serotonin levels can impair the central nervous system and cause fatigue and a decrease in performance (Bahrke \& Yesalis 
2002). Serotonin increase in the brain is due to increased levels of unbound tryptophan that are transported inside the brain. According to research, high levels of tryptophan along with low levels of BCAA cause fatigue in endurance exercise (Davis et al. 1995). By theory, since BCAA use the same transport mechanism as tryptophan, this would cause competitive binding between tryptophan and BCAA. It is believed that supplementation would increase BCAA concentrations in the body to the point that it would cause limited entry of tryptophan into the brain leading to less fatigue (Bahrke \& Yesalis 2002). However, the large amounts of BCAA that is required to limit tryptophan transport can increase ammonia in the body, which can limit brain and muscle metabolism and can slow water absorption (Bahrke \& Yesalis 2002). Furthermore there have been several studies (Varnier et al. 1994; Van Hall et al. 1995; Madsen et al. 1996) that have shown no advantages in performance when BCAA supplements were used. In regards to the claims that BCAA supplementation could augment protein synthesis, currently there have been no consistent studies showing improved nitrogen and protein balance or an anticatabolic effect following exercise (Jeukendrup and Gleeson 2004). Since BCAA are easily obtained through proper diet, and research has not shown conclusive evidence that supplementation would have ergogenic effects, supplementation is not recommended at this time (Williams 1999, Davis et al. 1995; Food and Nutrition Board 2005).

Lysine is required in the body for carnitine production in the liver, kidney and other tissues (Kohlmeier 2003; Food and Nutrition Board 2005). Carnitine is used in the metabolism of fats for energy by shuttling medium and long chain fatty acids into the 
mitochondria for beta oxidation (Kohlmeier 2003). Lysine deficiency can cause an adverse impact on fat metabolism. Lysine, when cross-linked by the enzyme lyoxidase, can also be used to produce proteins such as collagen and elastin which are found in the majority of the body's proteins (Springboard 2004). Excessive intake of lysine can cause kidney problems and doses greater than 1,500 mg per day should not be used. Lysine ingested with high amounts of arginine has been shown to increase synthesis of cholesterol along with low density lipoprotein (LDL) (Springboard 2004; Kohlmeier 2003). Acute high intakes of lysine have also been shown to compete with the transportation mechanism of arginine suggesting possible adverse effects (Food and Nutrition Board 2005). Protein obtained from meat generally is highly enriched in lysine. Although estimates of daily lysine requirements may vary slightly, it is approximately 30-31 mg/kg/d (Kohlmeier 2003; Food and Nutrition Board 2005). Large doses (above $10 \mathrm{~g} / \mathrm{d}$ ) can cause serious stomach cramps and diarrhea.

Methionine is an essential amino acid that is a large contributor of sulfur to the body. The sulfur composes disulfide linkages which form a secondary structure between parallel peptide chains. This helps proteins maintain their structural stability (Kohlmeier 2003). It also acts as a precursor for cysteine and S-adenosylmethionine (SAM). SAM is converted into homocysteine where it is used as a methyl donor group for the synthesis of adrenaline, creatine, melatonin, carnitine, taurine and several other compounds (Kohlmeier 2003, Di Pasquale 1997). Elevated homocysteine serum levels cause a high risk of heart disease and atherosclerosis; however, the reverse reaction (homocysteine to methionine) also occurs when there are adequate amounts of vitamin B-6. A high intake 
of methionine coupled with a deficiency in vitamin B-6 and an increased supplementation of methionine can lead to serious coronary artery disease (Springboard 2004; Food and Nutrition Board 2005). Methionine can be commonly found in cottage cheese, fish, poultry, and peanuts, and the recommended amount is $13-15 \mathrm{mg} / \mathrm{kg} / \mathrm{d}$ (Kohlmeier 2003;

Food and Nutrition Board 2005). Methionine supplementation is generally involved with burn and trauma patients, and currently there is little data regarding methionine and sports supplementation (Di Pasquale 1997).

Carnitine is a substance that is synthesized within the body from the amino acids lysine and methionine. It is generally found in red meat and dairy products, and to a lesser extent, plant foods (Bahrke and Yesalis 2002). About $90 \%$ of the body's source of carnitine is found in the muscle tissues (Williams 1999). Carnitine has several theorized actions including increasing $\mathrm{VO}_{2}$ max and reducing lactate production; however, its most popular claim is increasing fat metabolism (Jeukendrup and Gleeson 2004). In a fasting state or during exercise of low to moderate intensity, long-chain fatty acids are used as sources of energy (Jeukendrup and Gleeson 2004). Carnitine acts as a transporter during those times, and moves long-chain fatty acids into the mitochondria to be oxidized. Once in the mitochondria, the fatty acids go through beta-oxidation to produce acetyl-CoA that feeds into the Krebs cycle providing energy (Jeukendrup and Gleeson 2004, Bahrke and Yesalis 2002).

Carnitine will be often supplemented with the hope that increased concentrations would cause an increase in fatty acid mobilization and oxidation. In studies conducted by Barnet et al. (1994) and Vukovich et al. (1994) it was determined that oral carnitine 
ingestion ( $6 \mathrm{~g} /$ day up to 14 days) showed no change in muscle carnitine concentration. More recent studies have also come to the same conclusion: that carnitine supplementation does not increase fat oxidation, reduce glycogen breakdown, or improve performance (Heinonen 1996; Trappe et al. 1994). Due to the fact that the theorized ergogenic effects of carnitine have yet to be understood and proven, it is not recommended for supplementation (Williams 1998).

The majority of phenylalanine is converted into tyrosine by the enzyme phenylalanine hydroxylase. Tyrosine is a central compound and precursor to the manufacture of catecholamines (Di Pasquale 1997). Catecholamines are a family of hormones that include adrenaline and noadrealine from the central peripheral nervous system, and norepinephrine and epinephrine from the adrenal medulla. (Springboard 2004) These hormones deal with the management of blood pressure, stress, and anxiety. Phenylalanine is also known to be an antagonist of tryptophan. Phenylalanine increases the states of arousal, while tryptophan is used to induce sleep. Phenylalanine is found highest in legumes such as soybeans, and the recommended adult requirement is 27-39 $\mathrm{mg} / \mathrm{kg} / \mathrm{d}$ (Kohlmeier 2003; Food and Nutrition Board 2005). Adults with phenylketonuria, a genetic disease which prevents phenylalanine from being metabolized, should not exceed phenylalanine requirements (Food and Nutrition Board 2005). Currently there is not enough research data pertaining to phenylalanine supplementation, and; therefore, sports supplementation cannot be recommended.

Threonine is needed to synthesize glycine and serine in the body. They are required for the production of collagen, elastin, and muscle tissue (Kohlmeier 2003). 
Threonine can combine with other amino acids to help in the digestion of fats and fatty acids. Insufficient amounts of threonine can cause liver failure due to the build up of fats in the liver. Like most amino acids, they can be found in just about any food; however, animal and bean proteins have slightly higher concentrations than that of grains. It is recommended that adults obtain over $500 \mathrm{mg} /$ day or $16 \mathrm{mg} / \mathrm{kg} / \mathrm{d}$ for bodily functions (Kohlmeier 2003; Food and Nutrition Board 2005). Excessive amounts of threonine can disrupt liver function and cause the formation of excessive urea. No adverse effects of threonine supplementation have been documented; however, there is not enough research data pertaining to phenylalanine supplementation; therefore, threonine supplementation cannot be recommended (Food and Nutrition Board 2005).

Tryptophan forms an important neurotransmitter, serotonin. Serotonin is an intermediary product in the synthesis of melatonin which is a very powerful anti-oxidant (Di Pasquale 1997; Food and Nutrition Board 2005). Due to the synthesis of serotonin from tryptophan, it has been used to treat depression and insomnia effectively (Springboard 2004). It is also known to aid in weight-control by controlling diet due to the synthesis of serotonin and has been shown to aid in the release of human growth hormone (Kohlmeier 2003). However, the increase in growth hormone is so small that it has no significant impact on exercise performance (Springboard 2004). Milk and dairy products contain the highest levels of tryptophan, and it is recommended that $4-6 \mathrm{mg} / \mathrm{kg} / \mathrm{d}$ should be obtained for optimal health (Kohlmeier 2003; Food and Nutrition Board 2005).

Tryptophan started to be supplemented in hopes that it would decrease the perception of pain from increased levels of serotonin. In a study conducted by Stensrud et 
al. (1992), 49 well-trained individuals were exercised to exhaustion at $100 \% \mathrm{VO}_{2}$ max. There appeared to be no significant effect of tryptophan supplementation on performance. Van Hall et al. (1995) also conducted a similar study with eight cyclists and found no significant effects of tryptophan on performance. Besides the supposed decreased perception of pain, tryptophan may even have side-effects like decreased mental alertness, and sleepiness making it not necessarily the best ergogenic aid (Kohlmeier 2003). Athletes have been warned not to supplement with the free form of tryptophan since it has been associated with eosinophilia-myalgia syndrome (EMS) and has been banned by the FDA in North America (Di Pasquale 1997).

\section{Conditionally Essential Amino Acids}

The majority of the time arginine is synthesized in the liver and small intestine (Kohlmeier 2003). Its functions include phosphate storage in muscle since it is a precursor to creatine, and nitric oxide production which is an important blood pressure regulator in the body (Di Pasquale 1997, Kohlmeier 2003; Food and Nutrition Board 2005). It is also necessary for the excretion of urea from the body since it contributes to several amino acids in the urea cycle and can also enhance the secretion of insulin, prolactin (hormone for breast feeding), and growth hormone (Di Pasquale 1997; Food and Nutrition Board 2005).

The ability to stimulate growth hormone (HGH) and insulin allows arginine to theoretically have anticatabolic effects on skeletal muscle. HGH is known to increase muscle mass and decrease body fat (Bahrke \& Yesalis 2002). Although injecting large quantities of the amino acid directly into the body causes a slight increase in HGH, there 
has been no evidence that supplements increase HGH to a significant level (Lemon 1991, Lambert et al. 1993, Fogelholm et al. 1993). Several researchers reported that a dose of 30 grams in 30 minutes increased growth hormone and insulin. However, it should be noted that this is an unusually large amount of arginine, and supplements generally contain only between 1-2 grams per serving (Jeukendrup and Gleeson 2004). Larger doses of arginine through supplementation can cause severe gastrointestinal discomfort. Other reported side effects of larger doses $(10 \mathrm{~g} / \mathrm{d})$ are drowsiness and increased weight gain (Food and Nutrition Board 2005). Arginine is generally found in all food sources. Rice, oats, soy-beans, meats, fish, eggs, and most beans contain a particularly high level of arginine. Deficiencies of arginine are rare; however, it can cause growth failure, loss of muscle mass, and organ damage (Kohlmeier 2003). Dietary intakes are generally not needed since the body is capable of endogenous synthesis. Currently, an upper limit cannot be determined; however, dietary arginine supplementation is not advised unless there is medical need (Food and Nutrition Board 2005).

Cysteine is an amino acid that is converted from methionine. It is a precursor to taurine, serves as a free radical antioxidant in cellular systems, and blocks free radicals that are involved in aging, carcinogenesis, diabetes, and heart disease (Kohlmeier 2003; Food and Nutrition Board 2005). Cysteine is also involved in cellular glutathione which aids vitamin E to protect cells against free radical oxidant damage (Di Pasquale 1997). Deficiencies of methionine, vitamin B-12, or selenium will result in a poor metabolism of cysteine and reduced antioxidant protection (Kohlmeier 2003). When supplemented, cysteine must be in the form of N-acetyl-L-cysteine (NAC) since cysteine is readily 
oxidized in the gastrointestinal tract leading to toxic side effects (Di Pasquale 1997). Supplementation of L-cysteine given in five gram and 10 gram dosages were reported to cause nausea and light-headedness (Food and Nutrition Board 2005). Since there is not enough research data regarding NAC sport supplementation, recommendations cannot be given.

Glycine is the simplest amino acid; however, it has countless essential roles. Glycine has been shown to help construct genetic material such as deoxyribonucleic acid (DNA) and ribonucleic acid (RNA). It helps prevent the breakdown of muscle by boosting levels of creatine, and makes up approximately one-third of collagen, responsible for skin function (Di Pasquale 1997; Food and Nutrition Board 2005). Finally, it helps control gluconeogenesis and the formation of blood sugar from protein in the liver as well as the formation of bile for fat digestion (Kohlmeier 2003). Although glycine is not a very popular supplement, it is involved in the synthesis of phosphocreatine and release of growth hormone; therefore, it has been theorized to have ergogenic roles (Food and Nutrition Board 2005). However, there have not been enough studies or information to support or reject those claims (Jeukendrup and Gleeson 2004). Currently, there is also not enough research done on upper limit dosage of glycine in healthy individuals (Food and Nutrition Board 2005).

Proline is a nonessential amino acid that is involved in the production of collagen and cartilage. It is a precursor to hydroxyproline, a major molecule found in collagen (Kohlmeier 2003). Collagen is the most abundant protein in the body; it repairs cartilage and keeps muscles and joints flexible (Springboard 2004). It is found in just about every 
structure in the body. Proline can be synthesized from glutamate; therefore; supplementation is not needed with a proper diet. No adverse effects of proline supplementation have been documented; however, the effect of proline supplementation on the anabolic effects of exercise has not been adequately studied; therefore, supplementation recommendations cannot be made (Di Pasquale 1997; Food and Nutrition Board 2005).

Tyrosine is a non-essential amino acid that is converted from phenylalanine. It is important in regulating appetite, pain sensitivity, and the body's response to stress. In addition, it is needed for the proper functioning of the thyroid, pituitary, and adrenal glands (Kohlmeier 2003; Food and Nutrition Board 2005). These glands release catecholamines which deal with physical and emotional stress. Tyrosine can be supplemented to assist in treating disorders with low dopamine output such as depression (Springboard 2004). Along with the catecholamines, tyrosine is known to be the immediate precursor to the thyroid hormone thyroxin and melanin, involved in the pigmentation of skin during tanning (Di Pasquale 1997; Food and Nutrition Board 2005).

Supplementation in the athletic community is generally popular due to the hopes that tyrosine would activate metabolic pathways and alter hormone levels (Jeukendrup and Gleeson 2004). However, most tyrosine supplements contain such small doses that it probably cannot alter hormone levels (Jeukendrup and Gleeson 2004). There are currently no controlled studies that show tyrosine supplements have any ergogenic effects. Furthermore, chronic supplementation in large amounts $(5-10 \mathrm{~g} / \mathrm{d})$ can cause adverse effects to the sympathetic nervous system (Jeukendrup and Gleeson 2004). 
Non-Essential Amino Acids

Alanine is important in managing the proper blood glucose levels from dietary protein. It takes part in the glucose-alanine cycle. During the glucose-alanine cycle, glucose is oxidized in the muscle to pyruvate, which can then be converted to alanine. Alanine can be transported out of the cell and to the liver where it is converted back once more to pyruvate and then glucose. The liver would then release the glucose into the blood providing the body with more energy (Kohlmeier 2003). Good sources of alanine are meat, poultry, eggs, diary, and fish; however, since alanine is a non-essential amino acid, and the body is capable of producing it through many pathways, it is not necessary to supplement like all the other non-essential amino acids. Data is very limited on the upper limit for alanine (Food and Nutrition Board 2005).

Asparagine can be synthesized from aspartic acid using the enzyme asparagine synthase. It is heavily involved in the excretion of urea and toxic ammonia. It also functions as an amino donor in liver transamination processes. In addition, asparagine is known to help maintain equilibrium in the central nervous system and has therapeutic properties, but is toxic when used in excess (Kohlmeier 2003). The deficiency of asparagine and aspartic acid causes a buildup of nitrogen-containing toxic metabolites; however, deficiencies of asparagine are very rare. There is no data on the toxicity of asparagine as a single amino acid supplement, and currently there is no suggested need for supplementation in current literature (Kohlmeier 2003; Food and Nutrition Board 2005). 
Aspartic acid, also known as aspartate, is an important component in the Krebs cycle. It helps synthesize other amino acids such as asparagine, arginine, lysine, methionine, threonine, and isoleucine. Aspartic acid is involved in cellular energy production by transporting nicotinamide adenine dinucleotide (NADH) molecules inside the mitochondria, via the malate-aspartate shuttle, where the electrons from NADH are used to generate ATP (Kohlmeier 2003). It also removes excess toxic ammonia from cells (Di Pasquale 1997). A deficiency in aspartate can cause fatigue and depression. Supplementation with aspartic acid has not consistently shown any ergogenic effects in exercise performance; however, many athletes will still continue to supplement aspartate in hopes to improve aerobic exercise performance (Jeukendrup and Gleeson 2004; Di Pasquale 1997). Aspartate can reduce plasma ammonia accumulation, and since ammonia is associated with fatigue, theoretically, it should improve performance. In a study conducted by Maughan and Sadler (1983), there were no reported signs of increased performance when supplemented with six grams of aspartate. Presently, there seems to be no reports of the effectiveness of aspartate as a supplement (Food and Nutrition Board 2005).

Glutamic acid, also known as glutamate, helps transmit neural signals in the central nervous system. It can either be converted to glutamine or gamma-aminobutryic which also helps transmit neural signals. Glutamate functions as a regulator of glycogen synthesis, gluconeogenesis, and lipolysis, and can replenish the supply of Kreb cycle intermediates like alpha-ketoglutarate (Di Pasquale 1997). It is also a precursor to glutamine which in respect helps synthesize NAD and flavin adenine di-nucleotide 
(FAD) (Kohlmeier 2003). Glutamate has been thought to be involved in monosodium glutamate symptom complex (MSG) which causes a burning sensations, facial pressure, chest pain, headache, numbness, and drowsiness; however, firm evidence has not been established and there is presently no evidence that it has any impact on overall health (Food and Nutrition Board 2005)

Glutamine is a special amino acid in that it can pass through the blood-brain barrier. Once inside the brain, glutamine can convert to glutamic acid and increases levels of gamma-aminobutyic acid (Kohlmeier 2003). Both actions aid in proper brain function. When the brain is not receiving enough glucose, there is an increase of glutamine metabolism for energy making glutamine an important source of energy for the nervous system. Glutamine can also promote a healthy digestive tract by balancing acid and alkaline levels (Di Pasquale 1997). It is easily absorbed through the small intestine, and can prevent toxic ammonia buildup in the liver. Excess nitrogen in the liver will attach itself to glutamic acid to form glutaime instead of being converted to toxic ammonia (Di Pasquale 1997). Glutamine can maintain nitrogen balance by transporting the excess nitrogen to lacking areas.

Skeletal muscle tissue contains up to $60 \%$ glutamine, and since it can help prevent muscle breakdown by regulating levels of nitrogen and improve mental alertness, it is a popular ergogenic supplement (Kohlmeier 2003, Max 1990, Antonio 1999). Glutamine also plays a large role in immune function, acting as the major fuel source for lymphocytes, macrophages, and gut enterocytes (Bahrke \& Yesalis 2002, Max 1990). After prolonged exercise $\left(50 \%-70 \%\right.$ of $\left.\mathrm{VO}_{2} \max \right)$ a $10-30 \%$ fall of plasma glutamine 
concentration can be observed (Jeukendrup and Gleeson 2004). This is one of the reasons why risk of infection is higher after prolonged exercise (Walsh et al. 1998). In a study conducted by Castell et al. (1996), athletes were given either a placebo or a drink containing glutamine after heavy exercise and two hours after exhaustive exercise. Athletes reporting no infections were significantly higher in the glutamine supplementation group (81\%) compared to those in the placebo group (49\%). However, it was also reported that glutamine supplementation had no real effect on plasma glutamine levels (Castell et al. 1996). In other studies conducted by Gleeson and Bishop (2000), glutamine supplementation showed no beneficial effect on immune function as well. Low levels of glutamine causes increased acidity in the body leading to the loss of calcium, magnesium, sodium, and potassium. Since the body produces approximately 50-120 grams of glutamine a day, small amounts of glutamine in the form of supplements are unlikely to have any ergogenic effect, and are not recommended (Di Pasquale 1997).

Serine is a non-essential amino acid that can easily be synthesized from glycine. Serine is important in forming phospholipids found in every cell (Di Pasquale 1997). It also plays a large role in the central nervous system by forming protective myelin sheaths. Without serine, myelin sheaths would be less effective resulting in lowered mental function (Kohlmeier 2003). In order for serine to be manufactured in the body, adequate amounts of vitamin B3, vitamin B6, and folic acid must be present. Meat, soy, dairy, wheat gluten, and peanuts are all good natural sources of serine (Kohlmeier 2003). Although serine may be marketed as an ergogenic aid (due to reported claims of its anticortisol effects), there is not enough consistent research establishing its effect; therefore, 
recommendations on supplementation currently cannot be made (Di Pasquale 1997; Food and Nutrition Board 2005).

In summary, most individual amino acids lack research and data to safely recommended supplemental doses. Furthermore, it has not been shown that histidine, phenylalanine, threonine, alanine, asparagines, glycine, cysteine, glutamate, proline, and serine have any ergogenic effects in exercise performance.

Isoleucine, leucine, valine, tryptophan, arginine, aspartic acid, glutamine, and tyrosine, by theory, all have positive ergogenic effects. Some of the latter amino acids are even quite popular in the supplementation industry; however, few, if any studies, have shown that these amino acids increase performance as they are theorized to do. With proper diet, supplementation should not be required for any individual amino acids.

Further research is needed on the upper limits of all individual amino acid supplementation and dietary intake (Food and Nutrition Board 2005).

\section{Creatine}

Creatine, also known as alpha-methylguanidinoacetic acid, is a combination of three amino acids consisting of glycine, arginine, and methionine. Similar to many other supplements, it can naturally be synthesized within human body (Jose et al. 2002). The body produces about 1-2 grams per day (g/d) of creatine. This usually occurs in the liver and on a much smaller scale in the pancreas and kidney (Jose et al. 2002). A typical daily diet will also add an additional 1-2 g/d. Foods that are high in creatine include beef (4.5 $\mathrm{g} / \mathrm{kg})$, pork (5 $\mathrm{g} / \mathrm{kg})$, and fish (1.5-2.0 g/kg) (Balsom et al. 1994). Dietary creatine is absorbed by the body through the intestinal tract and is then moved to the blood, while 
endogenous creatine is transported directly to the blood. Muscle fibers are not able to synthesis creatine; therefore, the blood acts as a transporter to allow creatine to have access to required tissue, mainly the muscles (Jose et al. 2002, Greenhaff 1997).

Once in muscle cells, creatine is converted to phosphocreatine (PCr) by the creatine kinase enzyme. $\mathrm{PCr}$ is stored in the muscle tissue until exercise when $\mathrm{PCr}$ and adenosine diphosphate (ADP) can be rapidly converted into adenosine triphosphate (ATP), also known as energy. This rapid transformation of ADP to ATP allows the body to perform consistently at a high power output during short term muscular workloads. Supplementation of creatine is done in hopes of increasing creatine muscle stores ( $\mathrm{PCr}$ ) allowing for longer ADP to ATP turnover rates and to delay the use of anaerobic glycolysis leading to lactic acid production or accumulation. It is also used to assist in replenishing depleted creatine stores after heavy exercise (Powers 2006). The leftover creatine from the previous reaction is then recycled or transformed into creatinine $(\mathrm{Crn})$ which cannot be used by the body and is excreted in the urine (Jose et al. 2002). Total body creatine (TCr) is the amount of $\mathrm{PCr}$ and creatine in the entire body. Approximately $95 \%$ of the TCr can be found in skeletal muscle. Approximately $60-70 \%$ of the TCr that exists in muscle is in the form of $\mathrm{PCr}$ (Balsom et al 1994).

It has been shown that different types of muscle fibers have different concentrations of creatine and PCr. Fast-twitch muscle fibers (type II) have anywhere from 5-30\% more PCr content than slow-twitch (type I) muscle fibers (Conway \& Clark 1996). Fast-twitch muscle fibers are generally known as "explosive" muscles, and are used in anaerobic exercise involving short bursts such as weight lifting and sprinting. 
Conversely, slow-twitch fibers are generally used for long aerobic forms of exercise. These might include running, swimming, or tri-athlete events. In a study by Vandenborne et al. (1995), nuclear magnetic resonance (NMR) is used to confirm that PCr content is indeed higher in type II muscle fibers compared to type I. This is also consistent with the findings that sprinters have higher levels of $\mathrm{PCr}$ in their quadriceps compared to those of long-distance runners, since sprinters have an increased proportion of type II muscle fibers (Bernus et al 1993).

Currently the standard procedure for supplemental creatine intake is $20 \mathrm{~g} / \mathrm{d}$ for five-to-seven days. This is known as the "loading phase." During the first few days of the loading phase, creatine concentration levels are known to return to fasting levels after 5-7 hours of supplementation (Green et al. 1996, Harris et al. 1992). Therefore, it would be beneficial to take the 20 grams and break them into five gram doses taken four to five times per day (Jose et al. 2002). There have been many studies reporting an increase in TCr concentrations due to this loading phase. Several studies, using muscle biopsies, reported that the loading phase can cause a 17-24\% increase in TCr (Hultman et al. 1996; McKenna et al. 1999; Snow et al. 1998; and Volek et al. 1999). Following the loading phase the user requires $2 \mathrm{~g} / \mathrm{d}$ to maintain the increased TCr levels, which is known as the “maintenance phase.” In Hultman's (1996) study, two groups of participants were given the loading phase of creatine; however, only one group was given the maintenance phase. It was shown in the group without the maintenance dose muscle TCr declined to baseline levels within 28 days. The group with maintenance supplementation; however, retained their elevated levels of TCr (Hultman 1996). In another study by Vandeberghe, et al. 
(1997), it was demonstrated without maintenance supplementation (2 g/d) TCr levels returned to baseline levels in approximately four weeks as well.

The maintenance stage of creatine supplementation can be obtained purely through diet alone. Depending on diet; however, this can sometimes be difficult. Raw red meat and fish have the highest concentrations of creatine. A 4-ounce raw steak includes approximately 0.5 grams of creatine. A typical intake of creatine in a mixed diet is approximately 1.5 to $2.0 \mathrm{~g} / \mathrm{d}$ in meat consumers (Bahrke \& Yesalis 2002). Since food preparation is known to degrade some of dietary creatine, diet alone might not always supply an adequate amount for maintenance (Bahrke \& Yesalis 2002; Greenhaff 1997). Using the amount of creatine in steak listed above, to get the recommended maintenance dose (2g), a person would have to ingest a little more than one pound of steak per day (Bahrke \& Yesalis 2002).

It has been suggested that an additional carbohydrate-containing solution should be supplemented beside creatine. In a study, a simple carbohydrate solution consisting of 93 grams was taken along with creatine. The results showed that there was a $25 \%$ increase in muscle $\mathrm{TCr}$ (Green et al. 1996). It was also reported that a 47 gram dose of simple carbohydrates along with a 50 gram dose of protein would give the same desired effects as 93 grams of simple carbohydrates (Green et al. 1996). This would ideally produce peak creatine and insulin levels at the same time allowing greater muscle creatine accumulation (Jose et al. 2002). This increased uptake of creatine into muscle tissue could be due to the heightened insulin levels from the carbohydrate, which results in increased blood flow in the muscles (Green et al. 1996). Since creatine is transported 
through the blood, this would allow improved creatine availability to the muscle; however, there has not been significant evidence supporting this idea (Steenge 1998).

Creatine use has become one of the most popular ergogenic aids available. In the United States alone, over two million kilograms have been used per year in the past five years (Jose et al. 2002). Sales of creatine in the United States alone are over $\$ 100$ million dollars (Strauss 1998). Creatine users are generally younger males who participate in resistance training (Sheppard et al. 2000). However; when looking at the entire population, it has been estimated that about $28 \%$ of the National Collegiate Athletic Association athletes, $29 \%$ of the military, $45 \%$ of power athletes, and $57 \%$ of civilian health club members are users (Sheppard 2000, Rosen 1999, LaBotz 1999).

To cover the reported effectiveness of creatine, it is best to evaluate creatine supplementation dealing with specific groups depending on different types of exercise. The first type of exercise is short-term high intensity exercise. This includes any bout of exercise that is under 30 seconds. In a study by Kreider et al. (1998), 25 NCAA football players were recruited and given either a placebo or a creatine supplement for 28 days. Afterwards, maximal repetitions were conducted on bench press, squats, and the bicycle. It was reported that data collected in all individual exercises were higher in the creatine supplement group than in the placebo group (Kreider et al. 1998). In a similar study by Izquierdo et al. (2002), 19 trained male handball players were similarly assigned to either a placebo or creatine supplement group. Bench-press, half-squat, jump, and sprint tests were conducted before and after. Again, it was found that creatine supplementation showed an increase in body mass along with increased number of repetitions in the bench 
press, half press, sprint, and jump tests (Izquierdo 2002). In a study dealing with 100 meter sprints, it was shown that creatine supplementation increased the sprint velocity in athletes as well (Skare 2001).

In a study by Becque (2002), 23 weight-trained males were given either a placebo or creatine supplement for 42 days (20g/day for first five days, two $\mathrm{g} / \mathrm{d}$ for remainder). The supplementation group showed a $28 \%$ increase in the one rep maximum (RM) using an arm flexor compared to the placebo group, which only had a 16\% increase (Becque 2002). Perason et al. (1999) examined the effects of creatine supplementation with one RM of bench press. Similarly to Becque, the results showed an increase in one RM compared to those with the placebo. There seems to be a consistent trend of creatine supplementation increasing performance in exercise bouts under 30 seconds (Kelly \& Jenkins 1998, Kreider et al 1998, Volek et al 1999).

The next type of exercise is intermittent high-intensity exercise. This is the type of exercise that is most prevalent in all types of sports (Jose et al 2002). Intermittent means that there is a stoppage or break between exercise bouts. Examples of this would be tennis, weight lifting (more than one rep and one set), and more than one set of sprints. In a study done by Skare (2001), it was reported that men who took creatine had an improvement over the total time in six intermittent 60 meter sprints. The placebo group had no changes (Skare 2001). In another study by Preen et al. (2001), creatine supplementation improved sprint performance by a six percent increase in work production. In a different study, nine competitive squash players performed 10 sets of simulated play. Sets two through 10 completed by creatine users were finished in a 
significantly shorter time than those in the placebo group (Romer 2001). Several other studies have documented similar results showing creatine supplement improved performance in intermittent exercise (Rossouw et al. 2000, Cottrell et al. 2002).

The last category for exercise is aerobic endurance. The general consensus is that creatine supplementation decreases performance in aerobic exercise. This is most likely due to the lack of PCr use and the potential for body mass increase. This increase in body mass causes a higher absolute rate of $\mathrm{VO}_{2}$ (Jose et al 2002). Balsom (1993) and Stroud (1994) reported that creatine supplementation had no effects or impaired aerobic running performance. Thompson (1996) also reported that creatine supplementation had no effects on aerobic swimming performance. There have been consistent findings to show that creatine supplementation has no positive edge in aerobic bicycle exercise (Izquierdo et al 2002, Engelhardt et al 1998, Vandebuerie 1998).

Just like any type of supplement, creatine may also have its negative side-effects. One of the most prominent side-effects, although it may be considered as a positive effect, is an increase in body mass. It has been demonstrated that supplementation in short (10 days) or long term (10+ days) has always resulted in a 1-2\% increase in body mass (Volek 1999, Izquierdo et al. 2002, Williams et al. 1999, Volek et al. 1996). It has also been reported that males tend to have a greater increase in body mass than women (Mihic et al. 2000). It can be considered a negative side-effect when individuals are participating in an activity that considers weight gain as not beneficial such as marathon runners (Jeukendrup \& Gleeson 2003). 
Water retention is another highly common side-effect. Unfortunately, there are few studies that deal with this side-effect. Hultman's study reported that the initial increase in body mass was likely to be water retention since there was a 0.6 liter decline in urinary output after creatine supplementation (Hultman et al. 1996). In several studies using bio-impedance, it has been shown that there is water retention in the body's intracellular compartments within a matter of three days (Zeigenfuss et al. 1998, Ziegenfuss 1997).

Muscle cramps have also been reported as side effects; however, there has been little research dealing with it specifically. In two review articles, there were a large number of anecdotal reports of muscle cramping (Juhn \& Tarnopolsky 1998). Furthermore there has been a report finding that creatine supplementation causes an increase in anterior compartmental pressure in the lower leg following 20 minutes of running at $80 \%$ of maximal aerobic power (Schroeder et al. 2001). This increase in pressure could be a precursor of cramps. Although there have been many reports from consumers claiming muscle cramps with creatine supplementation, there has been no research that directly proves the relationship between them. The cramps may have been induced by the intensity of exercise or electrolyte imbalance (Jose et al. 2002).

Gastrointestinal (GI) complaints have been known to plague creatine users as well. It has been noted that if creatine powder has not been completely dissolved before ingestion, it can lead to some GI distress (Poortmans \& Francaux 2000). In another study by Juhn, it was reported that large doses of creatine $(40+\mathrm{g} / \mathrm{d})$ would cause nausea, vomiting, or diarrhea (Juhn et al. 1999). However, because there was no control group in 
the study, it is difficult to establish the relationship. The majority of research has not seen any relationship between GI distress and creatine supplementation (Volel et al. 1999, Kreider et al. 1999, Izquierdo et al. 2002). In a series of experiments dealing with creatine supplementation during football players' training, pre-season, and three-a-day training, no GI distress from creatine was noted (Greenwood et al. 1999, Kreider et al. 1999, Greenwood et al. 2000).

The last commonly noted side effect is detrimental renal function. Kuehl et al. (1998) found renal insufficiency in a 19-year old Division I football player taking a supplement dose of $10 \mathrm{~g} / \mathrm{d}$ for three months. In another study, Pritchard and Kalra (1998) found negative effects from creatine supplementation in an individual with pre-existing renal disease. The participant took $15 \mathrm{~g} / \mathrm{d}$ for seven days then took two $\mathrm{g} / \mathrm{d}$ for 49 days afterwards. Renal function returned to normal once he discontinued supplementation. In a study by Koshy (1999), it was reported that a patient had interstitial nephritis following creatine supplementation ( $20 \mathrm{~g} / \mathrm{d}$ for four weeks). Once again, kidney function became normal after cessation of supplementation. It should be noted that in two of the studies mentioned, the individuals were taking creatine in unusually large doses and that may have been the cause. There have been many studies reporting no forms of renal distress in its participants as well with proper dosage (Poortmans \& Rancaux 1997, Rasmussen et al. 1999, Almada et al. 2000). There still needs to be further research regarding creatine's long-term health effects (Jose et al 2002). 


\begin{abstract}
Summary
Although both creatine and protein can naturally be produced in the human body, many individuals seek supplementation for a number of different reasons ranging from inadequate diet an increased performance. Proper supplementation of both substances has been demonstrated in numerous studies to have positive effects on certain activities. Proper supplementation procedures for both substances have been highly recognized in many different studies as well. Although these supplements have been shown to be highly effective, it must be noted that the majority of the studies have been conducted with highly trained individuals or athletes, and not necessarily recreationally active individuals. Taking excessive amounts of either substance may lead to an increased risk of certain health complications.
\end{abstract}




\section{CHAPTER III}

\section{METHODOLOGY}

Research Design

This was a descriptive study analyzing the protein and creatine supplementation habits of college students at Kent State University (KSU). An electronic questionnaire was administered by email to a random sample of students from the undergraduate population (approximately 17,787 students) at the main campus of KSU. The time needed to complete the survey was approximately 5-10 minutes. The survey measured demographics, supplement use, and reasons for supplement use.

\section{Setting}

Kent State University is located in Kent, Ohio. As of 2006, Kent State's main campus has an enrollment of 17,787 undergraduates along with 4,530 graduate students. Kent State also has several regional campuses as well, adding an additional 11,313 students.

Kent State is a public Ohio university, ranked among the nation's top 77 public research universities, and among the 76 top colleges in community engagement (Kent State 2007). It is one of the largest Ohio universities and offers classes and degree programs for regional, national and international students. Currently KSU offers over 282 academic programs at the associate, bachelor, masters and doctorate level.

\section{Subjects}

Participants were recruited during the spring semester of 2008 with granted permission from the KSU Institutional Review Board. The inclusion criteria for 
participation included: ages $18-28$ years, not a parent, currently enrolled in college with six or more credit hours per semester, currently an undergraduate student, and taking some form of protein or creatine supplementation. These criteria were instilled with the hopes of collecting data from the "typical" college student. All participant information was kept anonymous.

\section{Survey}

The survey was an electronic survey administered through email by the Kent State Survey Research Laboratory. It consisted of three main sections (Appendix), and additional exclusion questions at the start of the survey. The exclusion questions were in the form of "yes" or "no" and determined if the participant was eligible for the survey. There were four exclusion questions: age, parenthood, credit hours, year in college, and supplement use. All exclusion questions were placed at the start of the survey except for the question dealing with supplement use. The question dealing with current supplementation was placed after the demographics portion of the survey, and is further discussed below. If any of the participants did not meet any of the inclusion criteria, they were immediately stopped, and not able to finish the survey.

Section I of the questionnaire asked about the participants' demographics. There were twelve questions dealing with age, weight, college major, class rank, current amount of credit hours, physical activity level, and whether they were currently participating in a NCAA sanctioned sport. Following Section I of the survey, the exclusion question determining whether the participants were taking protein or creatine supplements, was added. This would allow for demographic data to be collected about the non- 
supplementing population before dismissing them from the survey. Physical activity level questions were modified from a previous study (Ray et al. 2001).

Section II of the questionnaire determined the participants creatine supplementation habits. There were ten questions used to verify the amount of intake, how often supplements were taken, time of use, and reason for use. The questions that focused on supplementation habits were obtained from previous studies pertaining to creatine supplementation (Sheppard 2000; Ray et al. 2001). Reasons for supplement were also asked. Various reasons were listed and participants were able to make additional open-ended comments on their reasons. The questionnaire selections were gained from previous literature (Froiland 2004). The final question was an open-ended question allowing participants to list specific brands of creatine they were using.

Section III of the questionnaire included questions concerning protein supplementation. Similarly to section two, this section involved eight questions which documented the type of protein supplement, amount of intake, how often supplements were taken, time of use, and reason for use. These questions were obtained by modifying the creatine supplementation questions to fit accordingly. As with Section II, reasons for supplement use was added as the last question. Again, various reasons were listed and participants were able to make additional open-ended comments on their reasons. Popular reasons for supplementation use were acquired from previous literature (Froiland 2004). Questions from section II and section III were relevant to only those who were currently supplementing either protein or creatine. Depending on their supplemental status, the 
survey omitted either sections II or III from the survey to prevent those who were not supplementing from answering or seeing those questions.

$$
\text { Survey Administration }
$$

The survey was both approved by the Survey Research Laboratory and the KSU IRB before use. An online consent form explained the purpose of the study, anonymity of participation, and further contact information before the start of the survey. Students acknowledged that they had understood and consented to the study by continuing with the survey. Upon approval, a request was placed at the KSU Register's Office for all current student email information. A data file containing all current spring 2008 semester students' email addresses was obtained.

To apply random selection, the total number of email addresses was randomly split into groups of 4,000 students. A group of 4,000 students was then randomly chosen and the survey was then emailed to every individual in that group. A reminder email was sent weekly until a response was reported. Two groups of 4,000 students had the survey emailed to them and there was a response rate of $18.8 \%$; however, only $9.8 \%$ reported supplement use. Data collected was downloaded by the KSU Survey Research Laboratory and then entered into SPSS Desktop Statistical Analysis Software, Version 14.0 .

\section{Analysis}

Only completed surveys were included in data analysis. Participants were entered into SPSS using a numeric number; thus, allowing anonymity. Variables including age, marital status, parenthood, year in school, participation in a NCAA sport, and major were 
entered categorically. Continuous variables included physical activity levels, supplementation amount, and length of supplementation use. Descriptive calculations of frequency, mean, standard deviation, percentages, and ranges were computed. Chi-square tests with a $p \leq 0.05$ significance level was used to determine if there were gender differences in time of supplementation, reasons for supplementation, form of supplementation, and knowledge regarding ingredients found in the supplements. A ttest with $\alpha \leq 0.05$ significance level selected a priori was used to find whether there was significance difference in the amount of protein supplemented each day by each gender. Ratios comparing protein intake to body weight were also determined. 


\section{CHAPTER IV}

\section{JOURNAL ARTICLE}

Introduction

The popularity of the supplement industry has increased over the last three decades. In 1999, Americans spent \$1.4 billion on ergogenic aids and 1.2 million people reported using them regularly (Bovill et al. 2003). Some studies have shown anywhere from 40 to $79 \%$ of all college athletes take supplements in hopes of improving performance (Froiland 2004; Stephens 2001).

There have been numerous studies that include vitamin, mineral, herbal, macronutrient, and micronutrient supplements; however, there is a lack of studies that report supplement use of protein and creatine (two of the most popular performance enhancing supplements) in a college population (Nemet \& Eliakim 2007, Metzl et al 2001; Strauss 1998).

Protein is an essential nutrient that is commonly found in the majority of foods, and aids in the development, repair, and growth of body tissues. Current recommendations for protein (Recommended Dietary Allowance) are 0.8 grams per kilogram $(\mathrm{g} / \mathrm{kg})$ of body weight for adults $(\mathrm{g} / \mathrm{kg})$ (Williams 1998). This includes both supplemented and dietary protein (total). Due to increased muscle catabolism, athletes have a higher protein requirement than the average individual. Endurance athletes require about $1.2-1.4 \mathrm{~g} / \mathrm{kg} / \mathrm{d}$, while strength training individuals require anywhere form 1.4-1.7 $\mathrm{g} / \mathrm{kg} / \mathrm{d}$ of total protein (Lemon 1998, Lemon 2000, Tarnopolsky et al 1992, Lemon et al 1992 
Creatine is a combination of three amino acids consisting of glycine, arginine, and methionine. It is converted to phosphocreatine (PCr) in muscle cells. $\mathrm{PCr}$ is stored in the muscle tissue until exercise when PCr with adenosine diphosphate (ADP) can be rapidly converted into adenosine triphosphate (ATP), also known as energy. Supplementation of creatine is done in hopes of increasing creatine muscle stores $(\mathrm{PCr})$ allowing for longer ADP to ATP turnover rates (faster production of energy) and to delay the use of anaerobic glycolysis leading to lactic acid accumulation. Currently, the standard procedure for supplemental creatine intake is $20 \mathrm{~g} / \mathrm{d}$ for five-to-seven days. This is known as the "loading phase." The loading phase can cause a 17-24\% increase in TCr (Hultman et al. 1996; McKenna et al. 1999; Snow et al. 1998; and Volek et al. 1999). Following the loading phase, the user requires two $\mathrm{g} / \mathrm{d}$ to maintain the increased $\mathrm{TCr}$ levels, which is known as the "maintenance phase." This allows for TCr concentrations to remain elevated in the body for a longer period of time.

In the studies concerning protein and creatine, there seems to be misinformation on proper purpose, use, and dosage. Often supplements will be consumed in higher than normal doses. In some studies, it has been reported that $2.0-4.0 \mathrm{~g} / \mathrm{kg} / \mathrm{day}$ of protein is taken in hopes of maximizing muscle building. Furthermore, $65 \%$ of protein supplement users believed that protein is the body's energy source during short-term athletic events (Bovill et al. 2003; Lemon et al 1992). Misconceptions dealing with creatine are equally prevalent. In a study involving 52 athletes, 39 exceeded the recommended maintenance dosage of creatine per day. Eighteen of those 39 athletes took more than $3 \mathrm{~g} /$ day, another 
18 took over $9 \mathrm{~g} /$ day, and three of the players took 17-20 g/day (Juhn et al. 1999). In another study, 674 athletes were surveyed and more than $40 \%$ of the sample used an incorrect loading method for creatine. Additionally, 70\% took excessive amounts of creatine for the maintenance phase (Ray et al. 2001).

Even though both protein and creatine have been around for decades, and are two of the most frequently used supplements, there still appears to be a high number of misinformed users. Since there is an abundant amount of information documenting the proper usage for both supplements, it is concerning to see the large number of individuals who still lack the knowledge to use them correctly. Further research is needed to determine the supplementation practices in college students in hopes of educating the misinformed individuals.

The purpose of this study was to conduct a descriptive analysis of protein and creatine supplementation habits among college students (including National Collegiate Athletic Association student athletes) using a random sample at a public Midwestern state university. Furthermore, it was hypothesized that there would be a significance difference in supplemental knowledge and reasons for use depending on gender.

\section{Methods}

\section{Research Design}

This was a descriptive study analyzing the protein and creatine supplementation habits of college students at Kent State University (KSU). An electronic questionnaire was administered by email to a random sample of students from the undergraduate 
population (approximately 17,787 students) at the main campus of KSU. The time needed to complete the survey was approximately 5-10 minutes. The survey measured demographics, supplement use, and reasons for supplement use.

\section{Subjects}

Participants were recruited during the spring semester of 2008 with permission from the KSU Institutional Review Board. The inclusion criteria for participation included: ages 18-28 years, not a parent, currently enrolled in college with six or more credit hours per semester, currently an undergraduate student, and taking some form of protein or creatine supplementation. These criteria were instilled with the hopes of collecting data from the "typical" college student. All participant information was kept anonymous.

Survey

The survey was an electronic survey administered through email by the Kent State Survey Research Laboratory. It consisted of three main sections (Appendix), and additional exclusion questions at the start of the survey. The exclusion questions were in the form of "yes" or "no" and determined if the participant was eligible for the survey. There were four exclusion questions: age, parenthood, credit hours, year in college (question was combined with the question regarding credit hours), and supplement use. All exclusion questions were placed at the start of the survey except for the question dealing with supplement use. The question dealing with current supplementation was placed after the demographics portion of the survey, and is further discussed below. If 
any of the participants did not meet any of the inclusion criteria, they were immediately stopped, and not able to finish the survey.

Section I of the questionnaire asked about the participants' demographics. There were twelve questions dealing with age, weight, college major, class rank, current amount of credit hours, physical activity level, and whether they were currently participating in a NCAA sanctioned sport. Following Section I of the survey, the exclusion question determining whether the participants were taking protein or creatine supplements, was added. This would allow for demographic data to be collected about the nonsupplementing population before dismissing them from the survey. Physical activity level questions were modified from a previous study (Ray et al. 2001).

Section II of the questionnaire determined the participant's creatine supplementation habits. There were ten questions used to verify the amount of intake, how often supplements were taken, time of use, and reasons for use. The questions that focused on supplementation habits were obtained from previous studies pertaining to creatine supplementation (Sheppard 2000; Ray et al. 2001). Reasons for supplement were also asked. Various reasons were listed and participants were able make additional openended comments on their reasons. The questionnaire selections were gained from previous literature (Froiland 2004). The final question was an open-ended question allowing participants to list specific brands of creatine they were using. Section III of the questionnaire included questions concerning protein supplementation. Similarly to section two, this section involved eight questions which 
documented the type of protein supplement, amount of intake, how often supplements were taken, time of use, and reasons for use. These questions were obtained by modifying the creatine supplementation questions to fit accordingly. As with Section II, reasons for supplement use was added as the last question. Again, various reasons were listed and participants were able to make additional open-ended comments on their reasons. Popular reasons for supplementation use were acquired from previous literature (Froiland 2004). Questions from section II and section III were relevant to only those who were currently supplementing either protein or creatine. Depending on their supplemental status, the survey omitted either sections II or III from the survey to prevent those who were not supplementing from answering or seeing those questions.

\section{Survey Administration}

The survey was both approved by the Survey Research Laboratory and the KSU IRB before use. An online consent form explained the purpose of the study, anonymity of participation, and further contact information before the start of the survey. Students acknowledged that they have understood and consented to the study by continuing with the survey. Upon approval, a request was placed at the KSU Register's Office for all current student email information. A data file containing all current spring 2008 semester students' email addresses was obtained.

To apply random selection, the total number of email addresses was randomly split into groups of 4,000 students. A group of 4,000 students was then randomly chosen and the survey was then emailed to every individual in that group. A reminder email was 
sent weekly until a response was reported. Data collected was downloaded by the KSU Survey Research Laboratory and then entered into SPSS Desktop Statistical Analysis Software, Version 14.0.

Analysis

Only completed surveys were included in data analysis. Participants were entered into SPSS using a numeric number; thus, allowing anonymity. Variables including age, marital status, parenthood, year in school, participation in a NCAA sport, and major were entered categorically. Continuous variables included physical activity levels, supplementation amount, and length of supplementation use. Other data including weight and protein and creatine intake were entered as actual numbers when possible.

Descriptive calculations of frequency, mean, standard deviation, percentages, and ranges were computed. Chi-square tests with a $p \leq 0.05$ significance level was used to determine if there were gender differences in time of supplementation, reasons for supplementation, form of supplementation, and knowledge regarding ingredients found in the supplements. A t-test, with $\alpha \leq 0.05$ significance level, was used to find whether there was significance difference in the amount of protein supplemented each day by each gender. Ratios comparing protein intake to body weight were also determined.

\section{Results}

Surveys were sent to 8,000 students, and 1,500 students responded to the questionnaire showing a response rate of $18.8 \%$. There were 222 students that did not meet the inclusion criteria for the survey; therefore, they were not used in analyses. 
Among the 1,278 students who met the inclusion criteria, 1,149 (89.9\%) were not taking any form of protein or creatine supplementation. Their demographic information is shown in Table 1. There were 129 recorded supplement users. Participant demographic data is represented in Table 2. 
Table 1

Demographic Information of Non-Supplement Users

\begin{tabular}{|c|c|c|c|}
\hline \multicolumn{2}{|l|}{ Gender } & $\mathrm{N}$ & $\%$ \\
\hline & Male & 240 & 20.9 \\
\hline & Female & 908 & 79.1 \\
\hline & Total $^{\mathrm{a}}$ & 1148 & 100.0 \\
\hline \multirow[t]{8}{*}{ Age (years) } & & $\mathrm{N}$ & $\%$ \\
\hline & 18 & 159 & 13.9 \\
\hline & 19 & 258 & 22.5 \\
\hline & 20 & 222 & 19.3 \\
\hline & 21 & 225 & 19.6 \\
\hline & 22 & 154 & 13.4 \\
\hline & $23+$ & 52 & 11.3 \\
\hline & Total $^{\mathrm{a}}$ & 1148 & 100 \\
\hline \multicolumn{2}{|c|}{ Body Mass Index (BMI) } & $\mathrm{N}$ & $\%$ \\
\hline & $<16.5$ & 6 & $\overline{0.52}$ \\
\hline & $16.5-18.49$ & 41 & 3.6 \\
\hline & $18.5-24.99$ & 688 & 60.0 \\
\hline & $25-29.99$ & 264 & 23.0 \\
\hline & $30-34.99$ & 90 & 7.8 \\
\hline & $35-39.99$ & 37 & 3.2 \\
\hline & $40+$ & 21 & 1.8 \\
\hline & Total $^{\mathrm{a}}$ & $1147^{b}$ & 100.0 \\
\hline \multirow[t]{6}{*}{ Class Rank } & & $\mathrm{N}$ & $\%$ \\
\hline & Freshman & 280 & 24.4 \\
\hline & Sophomore & 284 & 24.7 \\
\hline & Junior & 241 & 21.0 \\
\hline & Senior & 343 & 29.9 \\
\hline & Total $^{a}$ & 1148 & 100.0 \\
\hline \multirow[t]{6}{*}{ Living Statu } & & $\mathrm{N}$ & $\%$ \\
\hline & Commuting & 247 & 21.5 \\
\hline & On Campus & 529 & 46.1 \\
\hline & Off Campus & 366 & 31.9 \\
\hline & Other & 6 & 0.5 \\
\hline & Total $^{\mathrm{a}}$ & 1148 & 100.0 \\
\hline \multicolumn{2}{|c|}{ Credit Hours } & $\mathrm{N}$ & $\%$ \\
\hline & $<11$ & 58 & 5.1 \\
\hline & $12-14$ & 376 & 32.8 \\
\hline & $15-17$ & 563 & 49.0 \\
\hline & $18+$ & 151 & 13.2 \\
\hline & Total $^{\mathrm{a}}$ & 1148 & 100.0 \\
\hline
\end{tabular}


Table 1 Continued

\begin{tabular}{|c|c|c|}
\hline NCAA Athletes & $\mathrm{N}$ & $\%$ \\
\hline Yes & 32 & 2.8 \\
\hline No & 1116 & 97.2 \\
\hline Total $^{a}$ & 1148 & 100.0 \\
\hline Strength Training (days/week) & $\mathrm{N}$ & $\%$ \\
\hline Never & 565 & 49.2 \\
\hline 1-2/week & 305 & 26.6 \\
\hline 3-4/week & 229 & 19.9 \\
\hline 5-6/week & 41 & 3.6 \\
\hline $7+/$ week & 8 & 0.7 \\
\hline Total $^{\mathrm{a}}$ & 1148 & 100.0 \\
\hline Strength Training (minutes per session) & $\mathrm{N}$ & $\%$ \\
\hline $0-19$ & 592 & $\overline{51.6}$ \\
\hline $20-39$ & 180 & 15.7 \\
\hline $40-59$ & 51 & 4.4 \\
\hline $60-79$ & 201 & 17.5 \\
\hline $80-140$ & 103 & 9.0 \\
\hline $140+$ & 21 & 1.8 \\
\hline Total $^{\mathrm{a}}$ & 1148 & 100.0 \\
\hline Aerobic Exercise (days/week) & $\mathrm{N}$ & $\%$ \\
\hline Never & 320 & 27.9 \\
\hline 1-2/week & 375 & 32.7 \\
\hline 3-4/week & 326 & 28.4 \\
\hline 5-6/week & 99 & 8.6 \\
\hline $7+/$ week & 28 & 2.4 \\
\hline Total $^{\mathrm{a}}$ & 1148 & 100.0 \\
\hline Aerobic Exercise (minutes per session) & $\mathrm{N}$ & $\%$ \\
\hline $0-19$ & 337 & 29.4 \\
\hline $20-39$ & 259 & 22.6 \\
\hline $40-59$ & 115 & 10.0 \\
\hline $60-79$ & 283 & 24.7 \\
\hline $80-140$ & 123 & 10.7 \\
\hline $140+$ & 30 & 2.6 \\
\hline Total $^{\mathrm{a}}$ & $1147^{\mathrm{a}}$ & 100.0 \\
\hline
\end{tabular}

\footnotetext{
${ }^{\mathrm{a}}$ one participant was eliminated from the total due to extremely irregular data
}

${ }^{\mathrm{b}}$ total percent of participants who gave a response; one missing (6818) 
Table 2

Demographic Information of Supplement Users

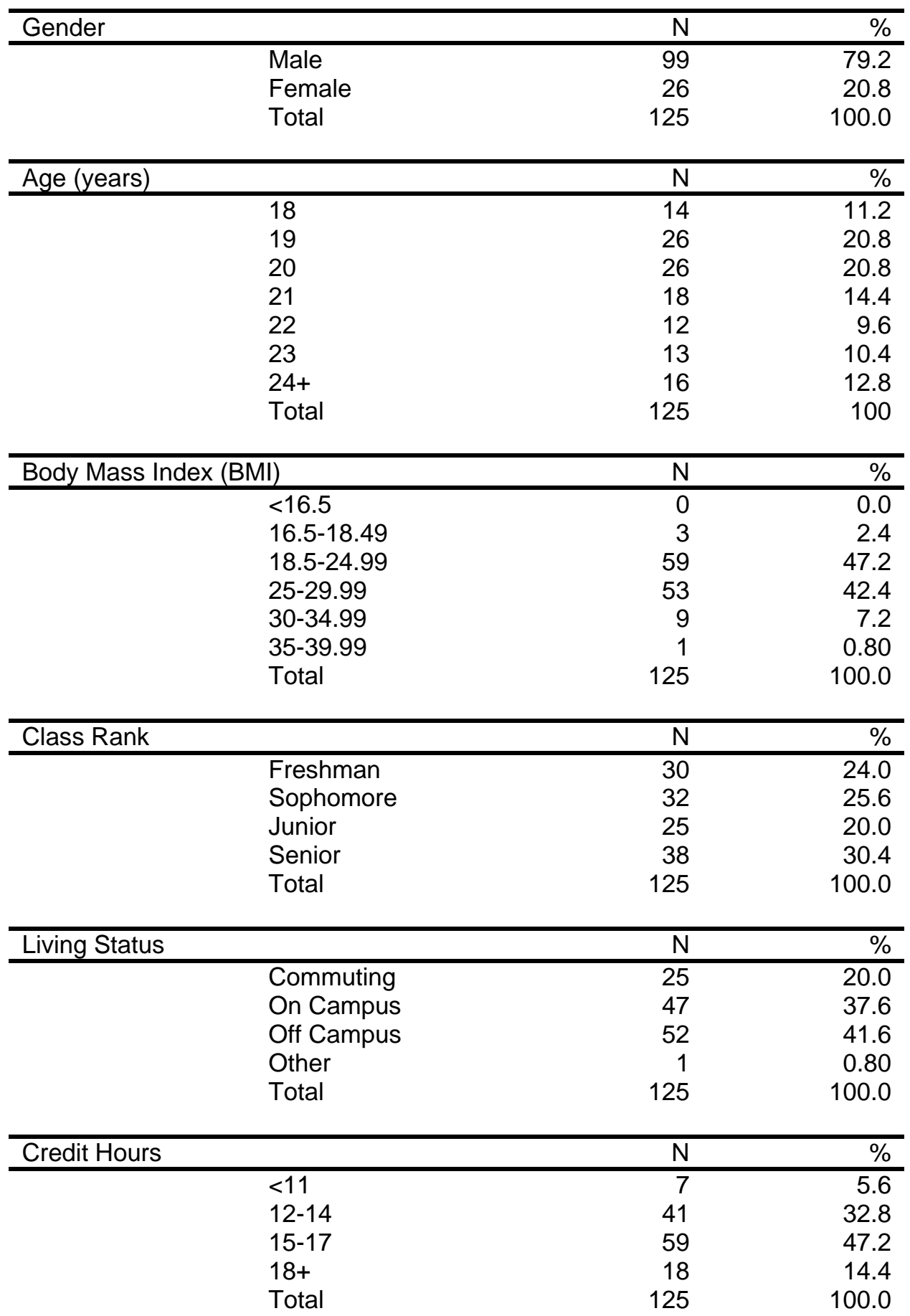


Table 2 Continued

\begin{tabular}{|c|c|c|}
\hline NCAA Athletes & $\mathrm{N}$ & $\%$ \\
\hline Yes & 11 & 8.8 \\
\hline No & 114 & 91.2 \\
\hline Total & 125 & 100.0 \\
\hline Strength Training (days/week) & $\mathrm{N}$ & $\%$ \\
\hline Never & 7 & 5.6 \\
\hline 1-2/week & 22 & 17.6 \\
\hline 3-4/week & 40 & 32.0 \\
\hline 5-6/week & 51 & 40.8 \\
\hline $7+/$ week & 5 & 4.0 \\
\hline Total & 125 & 100.0 \\
\hline Strength Training (minutes per session) & $\mathrm{N}$ & $\%$ \\
\hline $0-19$ & 7 & 5.6 \\
\hline $20-39$ & 9 & 7.2 \\
\hline $40-59$ & 7 & 5.6 \\
\hline $60-79$ & 54 & 43.2 \\
\hline $80-99$ & 22 & 17.6 \\
\hline $100+$ & 26 & 20.8 \\
\hline Total & 125 & 100.0 \\
\hline Aerobic Exercise (days/week) & $\mathrm{N}$ & $\%$ \\
\hline Never & 13 & 10.4 \\
\hline 1-2/week & 42 & 33.6 \\
\hline 3-4/week & 38 & 30.4 \\
\hline 5-6/week & 27 & 21.6 \\
\hline 7+/week & 5 & 4.0 \\
\hline Total & 125 & 100.0 \\
\hline Aerobic Exercise (minutes per session) & $\mathrm{N}$ & $\%$ \\
\hline $0-19$ & 22 & 17.6 \\
\hline $20-39$ & 44 & 35.2 \\
\hline $40-59$ & 18 & 14.4 \\
\hline $60-79$ & 23 & 18.4 \\
\hline $80+$ & 18 & 14.4 \\
\hline Total & 125 & 100.0 \\
\hline
\end{tabular}




\section{Creatine Users}

Of the 129 participants who recorded supplement use, there were only $42(32.5 \%)$ who recorded creatine use. All creatine supplement users were male, and the average class rank and age for creatine users were sophomores and 20 years of age. Creatine users, on average, did anaerobic exercise five times a week and aerobic exercise four times a week. Recorded data of creatine supplementation habits can be found in Table 3. Ten participants $(23.8 \%)$ reported using only creatine supplementation while the reminder of creatine users $(76.2 \%)$ also reported protein supplementation in addition to the creatine.

\section{Protein Users}

Of the 129 participants who reported supplement use, $119(92.2 \%)$ reported using protein supplements. Only $10(7.8 \%)$ supplement users reported not supplementing with protein. Data for protein supplementation habits can be found in Table 4. There were approximately three times as many male protein users when compared to females $(\mathrm{M}=$ $74.8 \% ; \mathrm{F}=25.2 \%$ ). A t-test was conducted and found significance in regards to protein supplementation between the genders. Table 5 represents a comparison of male and female responses to questions about supplementation practices and reasons for supplementation in regards to protein using a chi-square test. Significant differences were found in the post exercise time for supplementation, and the use of shake and bar form of protein for supplementation. Additionally, a comparison between gender and protein supplemented compared to body weight was completed and noted in Table 6 . In regards 
to the ratios of protein supplemented and bodyweight, the majority of both genders took less than $0.8 \mathrm{~g} / \mathrm{kg} /$ day of total protein, and very few participants in both genders took over $1.8 \mathrm{~kg} / \mathrm{g} /$ day of supplemented protein. 
Table 3

\section{Creatine Supplementation Habits}

\begin{tabular}{|c|c|c|}
\hline $\begin{array}{l}\text { How long have you been using creatine } \\
\text { (months) }\end{array}$ & Frequency & Percent \\
\hline $1-6$ & 15 & 35.7 \\
\hline $7-12$ & 10 & 23.8 \\
\hline $13-18$ & 0 & 0.0 \\
\hline $18-24$ & 4 & 9.5 \\
\hline $24+$ & 13 & 31.0 \\
\hline Total & 42 & 100.0 \\
\hline Do you load creatine & Frequency & Percent \\
\hline Yes & 6 & 14.3 \\
\hline No & 34 & 81.0 \\
\hline I m not sure & 2 & 4.8 \\
\hline Total & 42 & 100.0 \\
\hline How many days do you load creatine? & Frequency & Percent $^{\mathrm{a}}$ \\
\hline 5 & 4 & 66.7 \\
\hline Total & 4 & 100 \\
\hline How many grams of creatine during loading & Frequency & Percent \\
\hline 15.00 & 1 & 16.7 \\
\hline 20.00 & 1 & 16.7 \\
\hline 50.00 & 2 & 33.3 \\
\hline I'm not sure & 2 & 33.3 \\
\hline Total & 6 & 100.0 \\
\hline $\begin{array}{l}\text { How many grams of creatine do you take on } \\
\text { a daily basis or as a maintenance dose? }\end{array}$ & Frequency & Percent \\
\hline $1.00-2.00$ & 1 & 2.4 \\
\hline $3.00-9.00$ & 13 & 31.0 \\
\hline $10.00-25.00$ & 7 & 16.7 \\
\hline $110.00+$ & 2 & 4.8 \\
\hline I'm not sure & 19 & 45.2 \\
\hline Total & 42 & 100.0 \\
\hline
\end{tabular}


Table 3 Continued

\begin{tabular}{|c|c|c|}
\hline Ingredients added to creatine & Frequency & Percent $^{D}$ \\
\hline Water & 38 & 90.5 \\
\hline Carbohydrates & 7 & 16.7 \\
\hline Fat & 1 & 2.4 \\
\hline Nothing & 1 & 2.4 \\
\hline Carnitine & 1 & 2.4 \\
\hline Other Supplements & 12 & 28.6 \\
\hline Other & 5 & 11.9 \\
\hline Time of Creatine Ingestion & Frequency & Percent $^{b}$ \\
\hline Pre-Exercise & 42 & 100.0 \\
\hline Post-Exercise & 13 & 31.0 \\
\hline During Exercise & 1 & 2.4 \\
\hline Other & 1 & 2.4 \\
\hline Reasons for Creatine Use & Frequency & Percent $^{b}$ \\
\hline Increased Energy & 18 & 42.9 \\
\hline Weight/Muscle Gain & 37 & 88.1 \\
\hline Inadequate Diet & 2 & 4.8 \\
\hline Increased Performance & 25 & 59.5 \\
\hline Increased Fat Loss & 8 & 19.0 \\
\hline Weight Loss & 4 & 9.5 \\
\hline Other & 0 & 0 \\
\hline $\begin{array}{l}\text { Did you consult a physician, athletic trainer, or } \\
\text { dietitian before taking creatine? }\end{array}$ & Frequency & Percent \\
\hline Yes & 11 & 26.2 \\
\hline No & 31 & 73.8 \\
\hline
\end{tabular}

${ }^{a}$ Two participants omitted due to irregular data

${ }^{\mathrm{b}}$ Percent calculated with number of participants supplementing with protein (42) 
Table 4

\section{Protein Supplementation Habits}

\begin{tabular}{|c|c|c|}
\hline What is your gender? & Frequency & Percent \\
\hline Male & 93 & 78.2 \\
\hline Female & 26 & 21.8 \\
\hline Total & 119 & 100.0 \\
\hline $\begin{array}{l}\text { How long have you been taking a protein } \\
\text { supplement? (months) }\end{array}$ & Frequency & Percent \\
\hline$<6$ & 25 & 21.0 \\
\hline $6-11$ & 20 & 16.8 \\
\hline $12-23$ & 16 & 13.4 \\
\hline $24-35$ & 19 & 16.0 \\
\hline $36-59$ & 20 & 16.8 \\
\hline $48-59$ & 9 & 7.6 \\
\hline $60+$ & 19 & 16.0 \\
\hline Total & 119 & 100.0 \\
\hline $\begin{array}{l}\text { How many grams of protein do you } \\
\text { supplement daily? }\end{array}$ & Frequency & Percent \\
\hline $1.00-25.00$ & 19 & 16.0 \\
\hline $26.00-50.00$ & 23 & 19.3 \\
\hline $51.00-75.00$ & 18 & 15.1 \\
\hline $76.00-100.00$ & 8 & 6.7 \\
\hline $101.00-200.00$ & 8 & 6.7 \\
\hline $200.00+$ & 3 & 2.5 \\
\hline I'm not sure & 40 & 33.6 \\
\hline Total & 119 & 100.0 \\
\hline Forms of Protein Supplementation & Frequency & Percent $^{a}$ \\
\hline Shakes/Powder & 110 & 92.4 \\
\hline Bar & 60 & 50.4 \\
\hline Pills & 9 & 7.6 \\
\hline Other & 1 & 0.84 \\
\hline Ingredients added to protein & Frequency & Percent $^{\mathrm{a}}$ \\
\hline Whey & 97 & 81.5 \\
\hline Casein & 23 & 19.3 \\
\hline $\begin{array}{l}\text { Branched Chain } \\
\text { Amino Acids }\end{array}$ & 39 & 32.8 \\
\hline Glutamine & 43 & 36.1 \\
\hline Carnitine & 16 & 13.4 \\
\hline
\end{tabular}


Table 4 Continued

\begin{tabular}{|c|c|c|}
\hline Ingredients added to protein & Frequency & Percent $^{\mathrm{a}}$ \\
\hline Arginine & 27 & 22.7 \\
\hline Tyrosine & 25 & 21.0 \\
\hline Tryptophan & 15 & 12.6 \\
\hline Aspartic Acid & 15 & 12.6 \\
\hline Other & 8 & 6.7 \\
\hline Not Sure & 41 & 34.5 \\
\hline Time of Protein Ingestion & Frequency & Percent $^{\mathrm{a}}$ \\
\hline Pre-Exercise & 52 & 43.7 \\
\hline Post-Exercise & 99 & 83.2 \\
\hline During Exercise & 3 & 2.5 \\
\hline Other & 30 & 24.2 \\
\hline Reasons for Protein Use & Frequency & Percent $^{a}$ \\
\hline Increased Energy & 40 & 33.6 \\
\hline Weight/Muscle Gain & 90 & 75.6 \\
\hline Inadequate Diet & 19 & 16.0 \\
\hline $\begin{array}{l}\text { Increased } \\
\text { Performance }\end{array}$ & 43 & 36.1 \\
\hline Increased Fat Loss & 26 & 21.8 \\
\hline Weight Loss & 20 & 16.8 \\
\hline Other & 8 & 6.7 \\
\hline $\begin{array}{l}\text { Did you consult a physician, athletic trainer, } \\
\text { or dietitian before taking protein? }\end{array}$ & Frequency & Percent \\
\hline Yes & 17 & 14.3 \\
\hline No & 102 & 85.7 \\
\hline Total & 119 & 100.0 \\
\hline
\end{tabular}

${ }^{\text {a} P e r c e n t ~ c a l c u l a t e d ~ w i t h ~ n u m b e r ~ o f ~ p a r t i c i p a n t s ~ s u p p l e m e n t i n g ~ w i t h ~}$ protein (119) 
Table 5

Comparison of Male and Female Protein Supplement Users

\begin{tabular}{|c|c|c|c|c|}
\hline \multicolumn{2}{|c|}{ Form of Supplementation: } & Yes (\%) & No (\%) & $p$-value ${ }^{a}$ \\
\hline \multirow[t]{2}{*}{ Shake/Powder } & Male & $92(98.9)$ & $1(1.1)$ & \multirow{2}{*}{$<0.001$} \\
\hline & Female & $18(69.2)$ & $8(30.8)$ & \\
\hline \multirow[t]{2}{*}{ Bar } & Male & 42 (45.2) & 51 (54.8) & \multirow{2}{*}{0.030} \\
\hline & Female & $18(69.2)$ & 8 (30.8) & \\
\hline \multirow[t]{2}{*}{ Pill } & Male & $4(4.3)$ & 89 (95.7) & \multirow{2}{*}{0.011} \\
\hline & Female & 5 (19.2) & 21 (80.8) & \\
\hline \multirow[t]{2}{*}{ Other } & Male & $0(0.0)$ & $\begin{array}{l}93 \\
(100.0)\end{array}$ & \multirow{2}{*}{0.058} \\
\hline & Female & $1(3.8)$ & $25(96.2)$ & \\
\hline \multicolumn{2}{|c|}{ Time of Supplementation } & Yes (\%) & No (\%) & $p$-value ${ }^{\mathrm{a}}$ \\
\hline \multirow[t]{2}{*}{ Pre-Exercise } & Male & $44(47.3)$ & $47(50.5)$ & \multirow{2}{*}{0.209} \\
\hline & Female & $8(30.8)$ & $18(69.2)$ & \\
\hline \multirow[t]{2}{*}{ During Exercise } & Male & $3(3.2)$ & $90(96.8)$ & \multirow{2}{*}{0.354} \\
\hline & Female & $0(0.0)$ & $\begin{array}{l}26 \\
(100.0)\end{array}$ & \\
\hline \multirow[t]{2}{*}{ Post-Exercise } & Male & 88 (94.6) & $5(5.4)$ & \multirow{2}{*}{$<0.001$} \\
\hline & Female & $11(42.3)$ & $15(57.7)$ & \\
\hline \multirow[t]{2}{*}{ Other } & Male & $19(20.4)$ & $74(79.6)$ & \multirow{2}{*}{0.023} \\
\hline & Female & $11(42.3)$ & $15(57.7)$ & \\
\hline
\end{tabular}


Table 5 Continued

\begin{tabular}{|c|c|c|c|c|}
\hline $\begin{array}{l}\text { Items Mixed w/Proteir } \\
\text { Supplements }\end{array}$ & & Yes (\%) & No (\%) & $p$-value ${ }^{a}$ \\
\hline \multirow[t]{2}{*}{ Water } & Male & $64(68.8)$ & $29(31.2)$ & \multirow{2}{*}{0.485} \\
\hline & Female & $16(61.5)$ & $10(38.5)$ & \\
\hline \multirow[t]{2}{*}{ Fat/Lipids } & Male & $1(1.1)$ & 92 (98.9) & \multirow{2}{*}{0.595} \\
\hline & Female & $0(0.0)$ & $\begin{array}{l}26 \\
(100.0)\end{array}$ & \\
\hline \multirow[t]{2}{*}{ Carbohydrates } & Male & $6(6.5)$ & 87 (93.5) & \multirow{2}{*}{0.147} \\
\hline & Female & $4(15.4)$ & $22(84.6)$ & \\
\hline \multirow{2}{*}{$\begin{array}{l}\text { Other } \\
\text { Supplements }\end{array}$} & Male & $8(8.6)$ & $85(91.4)$ & \multirow[b]{2}{*}{0.122} \\
\hline & Female & $0(0.0)$ & $\begin{array}{l}26 \\
(100.0)\end{array}$ & \\
\hline \multirow[t]{2}{*}{ Carnitine } & Male & $0(0.0)$ & $\begin{array}{l}93 \\
(100.0)\end{array}$ & \multirow[b]{2}{*}{$\mathrm{N} / \mathrm{A}$} \\
\hline & Female & $0(0.0)$ & $\begin{array}{l}26 \\
(100.0)\end{array}$ & \\
\hline \multirow[t]{2}{*}{ Nothing } & Male & $1(1.1)$ & 91 (98.9) & \multirow{2}{*}{$<0.001$} \\
\hline & Female & $5(19.2)$ & & \\
\hline \multirow[t]{2}{*}{ Other } & Male & $45(48.4)$ & $48(51.6)$ & \multirow{2}{*}{0.021} \\
\hline & Female & $6(23.1)$ & $20(76.9)$ & \\
\hline $\begin{array}{l}\text { Reasons for Protein } \\
\text { Supplementation }\end{array}$ & & Yes (\%) & No (\%) & $p$-value \\
\hline \multirow[t]{2}{*}{ Increased Energy } & Male & $28(30.1)$ & $65(69.9)$ & \multirow{2}{*}{0.126} \\
\hline & Female & $12(46.2)$ & $14(53.8)$ & \\
\hline
\end{tabular}


Table 5 Continued

\begin{tabular}{|c|c|c|c|c|}
\hline \multirow{2}{*}{$\begin{array}{l}\text { Muscle/Weight } \\
\text { Gain }\end{array}$} & Male & $84(90.3)$ & $9(9.7)$ & \multirow[b]{2}{*}{$<0.001$} \\
\hline & Female & $4(15.4)$ & $22(84.6)$ & \\
\hline \multirow[t]{2}{*}{ Weight Loss } & Male & $10(10.8)$ & $83(89.2)$ & \multirow{2}{*}{0.001} \\
\hline & Female & $10(38.5)$ & $16(61.5)$ & \\
\hline \multirow[t]{2}{*}{ Increased Fat Loss } & Male & $19(20.4)$ & $74(79.6)$ & \multirow{2}{*}{0.479} \\
\hline & Female & 7 (26.9) & 19 (73.1) & \\
\hline \multirow[t]{2}{*}{ Inadequate Diet } & Male & $12(12.9)$ & 81 (87.1) & \multirow{2}{*}{0.084} \\
\hline & Female & 7 (26.9) & $19(73.1)$ & \\
\hline \multirow{2}{*}{$\begin{array}{l}\text { Increased } \\
\text { Performance }\end{array}$} & Male & $36(38.7)$ & $57(61.3)$ & \multirow[b]{2}{*}{0.269} \\
\hline & Female & 7 (26.9) & 19 (73.1) & \\
\hline \multirow[t]{2}{*}{ Other } & Male & $3(3.2)$ & $90(96.8)$ & \multirow{2}{*}{0.004} \\
\hline & Female & 5 (19.2) & $21(80.8)$ & \\
\hline \multicolumn{2}{|c|}{$\begin{array}{l}\text { Ingredients found in Protein } \\
\text { Supplements }\end{array}$} & Yes (\%) & No (\%) & $p$-value ${ }^{a}$ \\
\hline \multirow[t]{2}{*}{ Whey } & Male & $83(89.2)$ & $10(10.8)$ & \multirow{2}{*}{$<0.001$} \\
\hline & Female & $14(53.8)$ & $12(46.2)$ & \\
\hline \multirow[t]{2}{*}{ Casein } & Male & $20(21.5)$ & $73(78.5)$ & \multirow{2}{*}{0.037} \\
\hline & Female & $1(3.8)$ & $25(96.2)$ & \\
\hline \multirow[t]{2}{*}{ BCAA } & Male & 35 (37.6) & $58(62.4)$ & \multirow{2}{*}{0.009} \\
\hline & Female & $3(11.5)$ & $22(84.6)$ & \\
\hline
\end{tabular}


Table 5 Continued

\begin{tabular}{|c|c|c|c|c|}
\hline \multicolumn{2}{|c|}{$\begin{array}{l}\text { Ingredients found in Protein } \\
\text { Supplements }\end{array}$} & Yes (\%) & No (\%) & $p$-value \\
\hline \multirow[t]{2}{*}{ Carnitine } & Male & $14(15.1)$ & 79 (84.9) & \multirow{2}{*}{0.057} \\
\hline & Female & $1(3.8)$ & 24 (92.3) & \\
\hline \multirow[t]{2}{*}{ Tryptophan } & Male & $11(11.8)$ & 82 (88.2) & \multirow{2}{*}{0.165} \\
\hline & Female & $3(11.5)$ & 22 (84.6) & \\
\hline \multirow[t]{2}{*}{ Arginine } & Male & $24(25.8)$ & $69(74.2)$ & \multirow{2}{*}{0.028} \\
\hline & Female & $2(7.7)$ & 23 (88.5) & \\
\hline \multirow[t]{2}{*}{ Tyrosine } & Male & $21(22.6)$ & $72(77.4)$ & \multirow{2}{*}{0.085} \\
\hline & Female & $3(11.5)$ & 22 (84.6) & \\
\hline \multirow[t]{2}{*}{ Aspartic Acid } & Male & 12 (12.9) & 81 (87.1) & \multirow{2}{*}{0.132} \\
\hline & Female & $2(7.7)$ & 23 (88.5) & \\
\hline \multirow[t]{2}{*}{ Glutamine } & Male & $38(40.9)$ & 55 (59.1) & \multirow{2}{*}{0.012} \\
\hline & Female & 4 (15.4) & $21(80.8)$ & \\
\hline \multirow[t]{2}{*}{ Other } & Male & $7(7.5)$ & $86(92.5)$ & \multirow{2}{*}{0.533} \\
\hline & Female & $1(4.0)$ & $24(96.0)$ & \\
\hline \multirow[t]{2}{*}{ I'm Not Sure } & Male & $28(30.1)$ & 65 (69.9) & \multirow{2}{*}{0.041} \\
\hline & Female & $13(52.0$ & $12(48.0)$ & \\
\hline
\end{tabular}


Table 6

Comparison of Male and Female Protein Intake

\begin{tabular}{lll}
\hline & Male (\%) & Female (\%) \\
\hline Less than 0.8 g/kg/day & $42(45.2)$ & $6(23.1)$ \\
Within 0.8-1.8 g/kg/day & $20(21.5)$ & $2(7.8)$ \\
More than $1.8 \mathrm{~g} / \mathrm{kg} /$ day & $9(9.7)$ & $0(0.0)$ \\
I Don't Know & $22(23.7)$ & $18(69.2)$ \\
Total & $93(100)$. & $26(100.0)$
\end{tabular}


Open-ended Answers

In specific questions, participants were given the opportunity to briefly write in an answer which they thought would be more appropriate and specific than the pre-given answers. A summary of the statements can be found in Table 7. 
Table 7

Open Ended Answers

Please list brands of creatine you are currently taking (Top 5 brands

in no particular order)

1. NO Explode

2.GNC Creatine Mono-Hydrate

3. Muscle Tech Creakic

4. Kre-Alkalyn

5. Body Fortress

When do you take protein supplements?

1. Morning

2. Before bed

3. Evenly throughout the day

4. Every hour

5. As a meal replacement

6. In between meals

Do you mix/take protein supplements with anything?

1. Milk

2. Juice

3. Ice cream

4. Soy milk

5. Peanut butter

6. Fruit

Please indicate your reasons for using protein supplements.

1. Recovery

2. New vegetarian

3. Strengthen muscles and tendons to prevent injury

4. Broken ankle

5. Makes me feel full

Please list all protein supplements you are taking (top 5 answers in no particular order)

1. EAS 100\% Whey

2. GNC $100 \%$ Whey (Pro Performance)

3. Body Fortress

4. Optimum Nutrition $100 \%$ Whey

5. Cyto-Sport Muscle Milk 


\section{Discussion}

As early as the ancient Greek Olympic Games, there have been attempts at pushing the human body to a higher performance level. The nature of a person's athletic and performance abilities depends greatly on the genes that they have inherited. Not every person has the genetic potential to become an Olympic champion; however, with

the proper physiological, psychological, and biomechanical training, they can achieve their maximal physical potential. In the last 40 years, people have been conducting studies in hopes of improving training programs and maximizing the human potential. Even at the lower levels of competition and recreation, people are seeking out substances and methods to increase their own performance (Williams 1999).

Protein and creatine are two substances that have been shown in repeated studies to be effective in improving exercise training. Even though there are abundant studies dealing with the most beneficial methods for supplementing protein and creatine, the supplementation population seems to have many misconceived notions in regards to the process (Kristiansen et al. 2005; Jeukendrup and Gleeson 2004; Sheepard et al. 2000; Haymes 1991). A descriptive study of protein and creatine supplementation habits among college students was conducted at a public Midwestern state university. Creatine Use

When looking at the creatine data collected from the study, this study found similar conclusions about creatine when looking at the college population compared to other populations (Juhn et al. 1999; Metzl et al. 2001; Sheppard et al. 2000). It was not 
surprising to find that there were no females in the study that reported creatine use since the primary characteristic of creatine users is young males who participate in strength training activities (Sheppard et al. 2000). Only 42 out of 1,148 students reported using creatine and only six of those students reported loading with creatine. This is surprising since there is a general consensus that creatine supplementation should include a loading phase of 20 grams for 5-7 days (Hultman et al. 1996; Vandebrghe et al. 1997). It is also important to consider if the participants were loading correctly and the current investigation found that five out of the six participants either did not know how much they were using, or were using an incorrect amount for the loading phase. This improper procedure of creatine loading has been seen in previous studies before. In studies by Juhn et al. (1999) and Ray et al. (2001), it was reported that over $40 \%$ of the participants in each study reported improper creatine loading methods. It is important to stress the need to educate those supplementing the proper procedures for creatine usage. Improper use can lead to decreased efficiency along with potential health complications such as muscle cramps, gastrointestinal distress, and reduced renal function (Kuehl et al. (1998; Pritchard and Kalra 1998; Koshy 1999; Poortmans \& Francaux 2000; Juhn et al. 1999; Juhn \& Tarnopolsky 1998; Schroeder et al. 2001).

Nearly half (45\%) of the participants that were currently using creatine in the form of a maintenance supplement reported that they did not know how much creatine they were taking daily or as a maintenance dose. Recommended daily maintenance dosages of creatine is approximately two grams. Higher amounts $(>2 \mathrm{~g})$ have been shown 
not to have an increase in TCr (Hultman et al. 1996; Vandbrghe et al. 1997; Juhn et al. 1999). With that in mind, 41 of the 42 (98\%) participants in the current investigation using creatine were taking unnecessary amounts of creatine or did not know how much they were using. Two participants listed their daily creatine dosage as $110 \mathrm{~g} /$ day and 500 $\mathrm{g} /$ day. It is doubtful these two participants were taking such high dosages, showing increased evidence that this population is not knowledgeable about current creatine supplementation recommendations. These results are similar to a previous study by Juhn et al. (1999) which showed $75 \%$ of creatine users overdosing during the maintenance phase of creatine.

Besides the misconceptions dealing with creatine supplementation, there were some general false beliefs about creatine itself. Creatine is primarily used to increased performance by allowing an individual to have more ATP produced from the ATPphosphocreatine pathway. It is most beneficial in anaerobic activities (Powers 2006). When examining the reasons for creatine use, the most notable reasons marked were inadequate diet, increased fat loss, and increased weight loss. Unfortunately, for the participants, creatine does not improve or aid in any of those reasons. It has been documented that a simple carbohydrate solution taken along with creatine will cause an increase in TCr concentrations more so than taking creatine alone (Green et al. 1996). When looking at the responses given by the participants, only seven out of the 42 participants took creatine with some form of a carbohydrate. Again, this shows an inadequate amount of knowledge dealing with the most effective way to supplement 
creatine. The lack of general knowledge in regards to creatine and its use increases the chance for potential adverse affects that have been associated with creatine.

\section{Protein-Use}

Ninety-three male participants and 26 female participants reported using protein. There was a significant difference in the number of male and female protein users, but no difference in the amount of protein supplemented. Previous research has shown that athletes require anywhere from of 1.2-1.8 grams per kilogram per day (dietary and supplemented combined) for optimal performance (Lemon 1998, Lemon 2000, Tarnopolsky et al. 1992, Lemon et al. 1992). Even though there has been research that shows that a total protein intake of $2.4 \mathrm{~g} / \mathrm{kg} /$ day did not increase protein synthesis any more than $1.4 \mathrm{~g} / \mathrm{kg} /$ day many times athletes can be observed supplementing more than $2.0 \mathrm{~g} / \mathrm{kg} /$ day (Tarnopolsky 1992, Lemon et al. 1992). The current study showed that when compared to their body weight, out of the 79 participants who reported a specific amount of protein supplemented per day, only nine (11\%) supplemented above $2.0 \mathrm{~g} / \mathrm{kg}$ of body weight. All nine participants who supplemented above $2.0 \mathrm{~g} / \mathrm{kg}$ of body weight were males. This is a surprisingly positive turnout considering that in previous research studies it was common for participants to supplement above $2.0 \mathrm{~g} / \mathrm{kg} /$ day (Lemon 1992; Lemon 2000). Only 22 (27.8\%) students actually supplemented in the range of $0.8-1.8$ $\mathrm{g} / \mathrm{kg} / \mathrm{day}$, and the majority ( $60.8 \%$ ) supplemented under $0.8 \mathrm{~g} / \mathrm{kg} / \mathrm{day}$ (Table 6 ). This is actually under the recommended RDA amount, although, one must assume they are also ingesting protein through an ordinary diet as well (which is usually already above the 
RDA). More research needs to be conducted to determine whether the participants understood the proper supplementation dosage, or rather, it was purely coincidence.

Similar to the creatine users, there seems to be limited knowledge and awareness in regards to protein supplementation. There were 40 individuals $(33.6 \%)$ who were unaware of how much protein they were supplementing per day. A large difference between the genders can be noted here where $69.2 \%$ of females supplementing, compared to $23.7 \%$ of males, did not know the specific amount they were supplementing with. Reasons for supplementation were also another area with limited knowledge. The main function of protein is for building and repairing body tissue. Forty participants $(33.6 \%)$ reported taken protein for "increased energy." It has been well documented that protein is not a major source of immediate energy, and this misconception has been documented before (Bovill et al. 2003, Massad 1993, Lemon 2000, Lemon 1992, Bahrke \& Yesalis 2002). Another frequent reason for protein supplementation was increased fat loss or weight loss $(21.8 \%$ and $16.8 \%$ respectively). This may be another area of concern since protein supplementation is not really advised for either reason.

One unique aspect of this study was the comparison between supplementation habits of the genders. The current study showed several significant differences between the reasons for supplementation of the genders. Thirty-eight percent of the females reported weight loss as the reason for supplementation, while only $10.8 \%$ of males reported the same reason. There was no significant difference between males $(30.1 \%)$ and females $(46.2 \%)$ who chose "increased energy" as their reasoning. There also was no 
significant difference between the genders (20.4\% vs. $26.9 \%$ respectively) for those who reported "increased fat loss" as their reasoning. As noted, there seems to be some level of misunderstanding on the purpose of protein supplementation since they are being used for increased energy and as a weight loss mechanism.

Differences in supplementation habits can also be noted. Time of supplementation was one area with a large difference. The best time for protein supplementation is approximately one hour after exercise (Ivy et al. 1988, Rasmussen 2000, Lemon 2000). Although it was reported that $94.6 \%$ of the males took protein post-exercise, there was a significance difference in females who only took it $42.3 \%$ of the time post-exercise. When comparing the two most popular forms of protein supplementation (powder and bars), there was a significance difference between the use of both in gender. Females were more likely to be supplementing in bar form $(69.2 \%$ vs. $45.2 \%)$ while males were more likely to be using a powder or shake (98.9\% vs. $69.2 \%)$.

While these differences might be surprising with first glance, upon further assessment, it might not be that of a surprise. In this study, the main goal of supplementation for females was weight loss while the males wanted muscle and weight gain. Differences in time and forms of supplementation are most likely related to the reasons for supplementation. It would be reasonable for males to take protein postexercise more often since it is the optimal time for muscle building and repair. Females will be more likely to supplement throughout the day since their goals are not repairing muscle after exercise but rather weight loss. Furthermore, the higher incidence of bar use 
seen in females could be due to the ease of use as a meal replacement. The results of this study have also shown that $69.2 \%$ of females are not aware of the amount of protein they are supplementing. Again this supports the idea that females may not even be interested in the protein content of these bars, but rather, purely using them since they were an easy meal replacement. This is one aspect that was not incorporated into the survey, and is a likely limitation. During post-exercise, protein shakes and powders might be preferred in males more so since they allow higher doses of protein per serving compared to bars. This would allow males to achieve a high dose of protein quickly and more efficiently than other forms of supplementation.

Two habits that were frequent with the female gender were using protein bars as their main form of supplementation, and ingesting carbohydrates in conjunction with their protein. Ingesting carbohydrates along with protein is generally used to aid the protein synthesis (Rasmussen et al. 2000, Van Loon et al. 2000, Roy et al. 1997). This is more common in those who wish to achieve maximal body tissue repair after exercise. This would not necessarily be beneficial for those trying to lose weight (the main reason for female supplementation in this study) (Ma et al. 2005; Vermunt et al. 2003; Daniels 2003). Furthermore, protein bars generally contain a reasonably high percent of fat which would additionally hinder weight loss goals. The lack of knowledge may play a large role in these supplementation practices; however, additional studies need to be conducted to evaluate the rationale for both behaviors. 
Like past studies done by Bovill et al. (2003) and Massad (1993), very few participants $(14.1 \%$ of protein $\& 26.2 \%$ of creatine) sought out a physician, athletic trainer, dietitian, or health professional for consultation before taking creatine and protein supplementation. Other sources of supplement recommendations that may be less expensive and easier to access are national groups such as the American College of Sports Medicine (ACSM), and the American Dietetic Association (ADA).

\section{Applications}

The results of this study may be used to increase awareness, research and education regarding protein and creatine supplementation among college students. This study demonstrated that even with the extensive amount of information regarding the supplementation industry, there still seems to be some misconceptions on the topic. Looking at the data, it can be deduced that college students are not able to use it as a form of counsel. This shows the need for increased education regarding protein and creatine supplementation in the college population. By increasing awareness and educational programs, college consumers will likely have a better understanding of the proper usage of protein and creatine supplements. Furthermore, it will allow them to make a knowledgeable evaluation of whether supplementation is something they actually need.

Education materials on protein and creatine supplementation should be made more accessible to all students, and their supplementation should be discussed more extensively in nutritional courses or introductory science courses. A new form of educational system might be needed in hopes of increasing its effectiveness. One of the 
hurdles in nutrition and supplemental education is the lack of agreement on critical issues and the inconsistencies with recommendations from government and health agencies. A possible solution is to use broad information regarding function and purpose of supplements to increase student awareness. Teaching should not be focused on "official" guidelines (Makowske \& Feinman 2005).

The results of this study may also be used it to increase the awareness of strength and conditioning coaches, athletic coaches, and any form of recreational health center professional. Many times these individuals are the main source of consultation in college athletes and students; however, many times there is a lack of knowledge in this field (Mowe et al. 2008; Juzwiak et al. 2005; Turner \& Bass 2001; Juhn et al. 1999). These professionals should be encouraged to educate themselves more about the topic, and become more proficient in aiding students and seeking out students who may be improperly using protein and creatine.

One topic that this study has brought forth is the comparison between supplementation and gender. Again, this can be an additional area where increased awareness would be beneficial in health professionals. While there were fewer females taking protein supplements than males, the misconceptions regarding the topic were just as frequent as the males. The lack of awareness of protein supplementation in females was alarming with $69.2 \%$ not knowing the amount they supplemented each day. Since one possible complication from increased protein intake is increased urinary calcium loss, it is imperative that females, who have greater risk of osteoporosis, be further educated in 
the process of proper supplementation. The results from this study have also shown that there was a significant difference in gender (females were less likely to be aware) in regards to the knowledge of the different types of ingredients that was included in their protein supplements. Health professionals should be just as aware, if not more, when observing female supplementation in comparison to male supplementation. Additionally, education programs should be created that are not gender specific or oriented, thus, allowing equal female participation.

\section{Limitations}

One of the limitations in the study was that the survey was self-administered and self-reported. This method of data collection can lead to a lot of variability in the answers. Participants may not fully understand questions or instructions when completing the survey. Without anyone physically there to monitor the administration of the survey, participants could have easily skipped questions or guessed on questions in which they did not understand. It was noted in the results and discussion that some answers were either missing or grossly out of proportion, skewing the data. Finally, even though the survey was distributed randomly to get a good distribution of respondents, the limited geographical location (northeast Ohio) may prevent the data being valid in other areas and colleges in the United States. 


\section{Conclusion}

There were a total 1,277 participants who met the inclusion criteria, and only 125 out of those 1,277 were supplementing with protein, creatine, or both. The number of students supplementing was rather small $(9.8 \%)$ when compared to the sample size. However, when looking at the results, it was apparent that there still is a lack of knowledge regarding protein and creatine supplementation in both genders of the college population. There was a gender difference found in supplementation rationale; and both genders showed an apparent lack in supplemental knowledge. Considering the fact that most protein and creatine studies have been conducted on trained athletes and not regular individuals, and the large misconceptions dealing with overall knowledge and supplemental practices seen in this study, supplementation of both substances needs to be carefully evaluated. Furthermore, being that there have been very few studies regarding college students and protein and creatine supplementation, the results has brought some potential for further research ideas and areas of investigations. 
APPENDIX 
APPENDIX A

Consent Form 


\section{CONSENT FORM}

\section{PROTEIN AND CREATINE SUPPLEMENTATION HABITS AMONG COLLEGE UNIVERSITY STUDENTS}

The purpose of this survey is to collect data on protein and creatine supplementation habits among college students (including National Collegiate Athletic Association student athletes). Little information is known about protein and creatine supplementation practices in college students, and collected data will be beneficial in discovering individuals who may require additional education on supplementation procedures. Furthermore, this data can be used in future healthcare and research settings.

This questionnaire is completely anonymous and confidential. This survey poses no known risks to your health, and your name will not be associated with any of the results. No personal identifying information, i.e., name or student identification numbers, should be written or will be asked during the survey.

Taking this survey is completely optional. If you feel uncomfortable at anytime, or wish to stop at anytime, you may do so. There is no penalty for refusing to participate, or for stopping at anytime throughout the survey. By continuing to the first question of the survey, you are hereby implying consent.

If you are curious and would like to learn more about this research project, please feel free to call or email me (Tel: 330.554.5312; Email: sbui@kent.edu). My advisors are Dr. Angie Ha and Dr. Natalie Caine-Bish (Tel: 330-672-2197). This project has been approved by Kent State University. If you have any questions or would like to learn more about Kent State University's rules for research, please call Dr. John L. West, Vice President and Dean of the Division of Research and Graduate Studies (Tel: 330.672.2704)

\section{Yours Sincerely,}

Angie Ha, Ph.D.

Assistant Professor and Advisor

School of Family and Consumer Studies

Kent State University

Steve Bui, B.S.

Principal Investigator

School of Family and Consumer Studies

Kent State University
Natalie Caine-Bish, Ph.D., R.D., L.D.

Assistant Professor and Advisor

School of Family and Consumer Studies

Kent State University 
APPENDIX B

Protein and Creatine Supplementation Habits

Among University Students Survey 
Please circle the appropriate answers to the following questions:

\section{Exclusion Questions}

1. Are you between the ages of $18-28$ ?
a. Yes
b. No

2. Are you an undergraduate student and taking 6 or more credit hours this semester?
a. Yes
b. No

3. Do you have children?
a. Yes
b. No

\section{Section I: Demographics}

1. What is your age?

2. What is your height? __ $\mathrm{ft} \_$inches

3. What is your weight in pounds?

4. Are you married?
a. Yes
b. No

5. What is your class rank?
a. Freshman
b. Sophomore
c. Junior
d. Senior

6. What is your major?

7. How many credit hours are you taking this semester?

8. Are you an NCAA athlete or have been within the last academic year?
a. Yes
b. No

9. In a typical week, how many days do you engage in strength training activities such 
as weightlifting?
a. Never
b. $1 /$ week
c. 2/week
d. 3/week
e. $4 /$ week f. 5/week
g. 6/week

f. $7+/$ week

10. If you engage in strength training, what is the average length of your training session? hours minutes

11. On average, how many days do you engage in aerobic activities such as running, swimming, bicycling, or some form of an elliptical machine?
a. Never
b. $1 /$ week
c. $2 /$ week
d. 3/week
e. $4 /$ week f. $5 /$ week
g. 6/week
f. $7+/$ week

12. If you engage in an aerobic activity, what is the average length of your aerobic activity in each session?

hours minutes

\section{Exclusion Question}

1. Are you currently taking any protein or creatine supplements?
a. Yes
b. No

\section{Section II: Creatine Use}

1. Do you use oral creatine?
a. Yes
b. No

2. Approximately how long have you been taking oral creatine? years __ months

3. Do you load creatine (take large doses and then reduce to a daily maintenance dose)?
a. Yes
b. No
c. I'm not sure 
4. How much oral creatine do you take when you load? (Please indicate how many grams per day and for how many days. Example: 3 grams per day for 5 days)
a. grams per day for days
b. Other (please specify)
c. I'm not sure
d. I do not load creatine

5. How much creatine do you take on a daily basis or as a maintenance dose? grams I I don't know

6. When do you take creatine? (Please mark all that apply)
a. pre-exercise
b. post-exercise
c during exercise
d. other (please specify)

7. Do you mix/take oral creatine with anything? (Please mark all that apply)
a. Water
b. Fat
c. Carbohydrates
d. Other supplements
e. Carnitine
f. Nothing
g. Other (please specify)

8. Did you consult a physician, athletic trainer, or dietitian/nutritionist before taking creatine?
a. Yes
b. No

9. Please indicate your reasons for using creatine (Please mark all that apply)
a. Increased energy
b. Weight Gain/Muscle Gain
c. Weight Loss
d. Increase Fat Loss
e. Inadequate Diet
f. Increased Performance
g. Other (please specify) 
10. Please list all the creatine supplements you are currently taking (Please be specific as possible including brand/and or names)

\section{Section III: Protein Use}

1. Do you use any form of protein supplements?
a. Yes
b. No

1. Please indicate what forms of protein supplementation do you take? (please mare all that apply)
a. Shakes/Powders: (eg: Designer Protein, Methoxy-Pro, Nitro-Tech, EAS Whey, GNC Pro Perforamance)
b. Bar (eg: Protein Plus by MET-Rx; Power Bar by Power Bar; Clif Bar by Clif Bar)
c. Pills (eg: Puritan Pride; ProteinEX)
d. Other (please specify):

2. Please indicate what types of ingredients are included in your protein supplement (please mark all that apply)
a. Whey
b. Casein
c. Branched Chained Amino Acids (Leucine, Isoleucine, Valine)
d. Carnitine
e. Tryptophan
f. Arginine
g. Tyrosine
h. Aspartic Acid/Aspartate
i. Glutamine
j. Other (please specify):
k. I'm not sure

3. How long have you been taking protein supplements? years months 
4. Approximately how many grams of protein do you supplement a day? grams

5. When do you take protein supplements? (Please mark all that apply)
a. pre-exercise
b. post-exercise
c during exercise
d. other (please specify)

6. Do you mix/take the protein supplements with anything? (Please mark all that apply)
a. Water
b. Fat
c. Carbohydrates
d. Other supplements
e. Carnitine
f. Nothing
g. Other (please specify)

7. Did you consult a physician, athletic trainer, or dietitian/nutritionist before taking protein supplements?
a. Yes
b. No

8. Please indicate your reasons for using protein supplements (Please mark all that apply)
a. Increased energy
b. Weight Gain/Muscle Gain
c. Weight Loss
d. Increase Fat Loss
e. Inadequate Diet
f. Increased Performance
g. Other (please specify)

9. Please list all the protein supplements you are currently taking (Please be specific as possible including brand/and or names) 
REFERENCES 


\section{REFERENCES}

ACSM. (2006). ACSM's guidelines to exercise testing and prescription (7th ed.).

Baltimore, MD: ACSM.

Almada AL, Kreider R, Melton C, \& et al. (2000). Long term creatine supplementation does not affect markers of renal stress in athletes [abstract]. J Strength Cond Res, 14, 359.

Antonio J, \& Street C. (1999). Glutamine: A potentially useful supplement for athletes. Can J Appl Physiol, 24, 1-14.

Archer SL, Stammer J, \& et al. (2005). Association of dietary supplement use ith specific micronutrient intakes among middle-aged american me and women: The INTERMAP study. J Am Diet Assoc, 105, 1106-1114.

Bahrke Michael, \& Yesalis Charles. (2002). Performance-enhancing substances ins sport and exercise. Champaign, IL: Human Kinetics.

Balsom P.D., Soderlund K, \& Ekblom B. (1994). Creatine in humans with special reference to creatine supplementation. Sports Medicine, 18, 268-280.

Balsom PD, Harridge SDR, Soderlund K, Sjodin B, \& Ekblom B. (1993). Creatine 
supplementation per se does not enhance endurance exercise performance. Acta Physiologica Scandinavica, 149, 521-523.

Barnett C, Costill D, Vukovich M, Cole J, Goodpaster B, Trappe S, et al. (1994). Effect of 1-carnitine supplementation on muscle and blood carnitine content and lactate accumulation during high-intensity sprint cycling. Int J Sports Nutr, 4(3), 280-288.

Becque, M., Lochmann JD, \& Melrose DR. (2000). Effects of oral creatine supplementation on muscular strength and boyd composition. Medicine and Science in Sports and Exercise, 32, 654-658.

Berdanier C. (2000). Advanced nutrition: Macronutrients (2nd ed.). Boca Raton, FL: CRC Press.

Bernus G, Gonzalez de Suso JM, Alonso J, \& et al. (1993). P-MRS of quadriceps reveals quantitative differences between sprinters and long-distance runners. Med Sci Sports Exerc, 25, 479-484.

Blendon RJ, Desroches CM, Benson JM, Brodie M, \& Altman DE. (2001). Americans' views on the use and regulation of dietary supplements. Arch Intern Med, 161, 805810. Bovill M. (2003). Nutrition knowledge and supplement use among elite us army soliders. 
Military Medicine, 163(12), 997.

Burke L.M., \& Read R.S.D. (1993). Dietary supplements in sport. Sports Medicine, 15, 43-65.

Castell L.M. et al. (1996). Does glutamine have a role in reducing infections in athletes? Eur J Appl Physiol, 73, 488-490.

Conway M.A., \& Clark J.F. (Eds.). (1996). Creatine and creatine phosphate: Scientific and clinical perspectives. San Diego (CA): Academic Press.

Cottrell G.T., Coast J.R., \& Herb R.A. (2002). Effect of recovery interval on multiplebout sprint cycling performance after acute creatine supplementation. J Strength Cond Res, 15, 109-116.

Daniels S. (2003). Abnormal weight gain and weight management: Are carbohydrates the enemy? Journal of Pediatrics, 142(3), 225-227

Davis J.M. et al. (1995). Effects of carbohydrate feedings on plasma free tryptophan and branched-chain amino acids udring prolonged cycling. Eur J Appl Physiol, 65(513 (Suppl 5)), S29.

Di Pasqual M. (1997). Amino acids and proteins for the athlete: The anabolic edge. Boca Raton, Florida: CRC Press. 
Doyle, A. (1998). Aerobic exercise main page. Retrieved 09/22, 2007, from http://www2.gsu.edu/ wwwfit/aerobice.html

Driskell J. (2000). Sports nutrition (1st ed.). Boca Raton, Florida: CRC Press.

Edmonds B. (2004). Consumers' confidence in supplements rises. Natural Foods Merchandiser, 25(18)

Engelhardt M., Neumann G., Berbalk A., \& Reuter I. (1998). Creatine supplementation in endurance sports. Medicine and Science in Sports and Exercise, 30, 1123-1129.

Fogelholm G., Naveri H., Kiilavuori K., \& Harkonen M. (1993). Low dose amino acid supplementation: No effects on serum growth hormone and insulin in male weightlifters. Int J Sports Nutr, 3, 290-297.

Food and Drug Administration (a). Overview of dietary supplements. Retrieved September 20, 2007, from http://www.cfsan.fda.gov/ dms/ds-oview.html\#what

Food and Drug Administration (b). Overview of dietary supplements. Retrieved September 20, 2007, from http://www.cfsan.fda.gov/ dms/dietsupp.html

Food and Nutrition Board \& Institute of Medicine. (2005). Dietary reference intakes for energy, carbohydrate, fiber, fat, fatty acids, cholesterol, protein, and amino acids (macronutrients)The National Academies Press. 
Froiland K. (2004). Nutritional supplement use among college athletes and their sources of information. Int J Sport Nutr Exerc Metab, 14, 104-120.

Gleeson M., \& Bishop N. (2000). Elite athlete immunology: Importance of nutrition. Int J Sports Med, 21(Suppl 1), S44-S50.

Green A.L., Simpson E.J., Littlewood J.J., \& et al. (1996). Carbohydrate ingestion augments creatine retention during creatine feeding in humans. Acta Physiol Scand, $158,195-202$.

Greenhaff, P.L. (1997). The nutritional biochemistry of creatine. Journal of Nutritional Biochemistry, 11, 610-618.

Greenwood M., Greewould L.D., Kreider R., \& et al. (2000). Effects of creatine supplementation on the incidence of cramping/injury during college football three a day training [abstract]. Med Sci Sports Exerc, 32, S136.

Greenwood M., Kreider R., Rasmussen C., \& et al. (1999). Creatine supplementation does not increase incidence of cramping or injury during college football training: II. Strength Cond Res, 13, 425-426. 
Harris R.C., Soderlund K., \& Hultman E. (1992). Elevation of creatine in resting and exercised muscle of normal subjects by creatine supplementation. Clin Sci, 83, 18021803.

Haymes E.M. (1991). Vitamin and mineral supplementation to athletes. International Journal of Sports Nutrition, 1, 146-169.

Healthy Competition. (2002). Blue Cross/Blue shield national performance-enhancing drug study. Retrieved 09/22, 2007, from www.healthycompetition.org

Heinonen O. (1996). Carnitine and physical exercise. Sports Med, 22(2), 109-132.

Hultman E., Soderland K., Timmons J.A., Cederblad G., \& Greenhalff P.L. (1996). Muscle creatine loading in men. Jounral of Applied Physiology, 81, 232-237.

Ivy J. (2000). Optimization of glycogen stores. In Maughan RJ (Ed.), Nutrition in sport (pp. 97-111)Blackwell Science.

Ivy J.1., Katz A.L., \& Culter C.L. et al. (1988). Muscle glycogen synthesis after exercise: Effect of time of carbohydrate ingestion. J Appl Physiol, 64, 1480-1485.

Izquierdo M., Ibanez J., Gonzalez-Badillo J.J., \& et al. (2002). Effects of creatine supplementation on muscle power, endurance, and sprint performance. Med Sci Sports Exerc, 34, 332-343. 
Jacobson B.H., \& Gemmell H.A. (1991). Nutrition information sources of college varsity athletes. J Appl Sport Sci Res, 5, 204-207.

Jeukendrup A., \& Gleeson M. (2003). Sport nutrition: An introduction to energy production and performance (1st ed.). Champaign IL: Human Kinetics.

Mesa J., Ruiz J., Gonzalez-Gross M., Gutierrez Sainz A., \& Castillo Garzon M. (2002). Oral creatine supplementation and skeletal muscle metabolism in physical exericse. Sports Medicine, 32(14), 903-943.

Juhn M.S., O'Kane J.W., \& Vinci D.M. (1999). Oral creatine supplementation in male collegiate athletes: A survey of dosing habits and side effects. J Am Diet Assoc, 99, 593-595.

Juhn M.S., \& Tarnopolsky M. (1998). Oral creatine supplementation and athletic performance: A critical review. Clin J Sport Med, 8, 286-297.

Juzwiak C.R., Ancona-Lopez F. (2004). Evaluation of nutrition knowledge and dietary recommendations by coaches of adolescent Brazilian athletes. Int J Sport Nutr Exerc Metab, 15(3), 217 
Kelly V.G., \& Jenkins D.G. (1998). Effect of oral creatine supplementation on nearmaximal strength and repeated sets of high-intensity bench press exercise. Journal of Strength and Conditioning Research, 12, 109-115.

Kent State University. (2007). Academics. Retrieved 11/24/07, 2007, from http://www.kent.edu/Academics/

Kohlmeier M. (2003). Nutrient metabolism. San Diego, California: Academic Press.

Koshy K.M., Griswold E., \& Schneeberger E.E. (1999). Internal nephritis in a patient taking creatine. $N$ Engl $J$ med, 340, 814-815.

Kreider R., Ferreira M., Wilson M., Grindstaff P., Plisk S., Reinhardy J., et al. (1998). Effects of creatine supplementation on body composition, strength, and sprint performance. Medicine and Science in Sports and Exercise, 30, 73-82.

Kreider R., Melton C., Hunt J., \& et al. (1999). Creatine does not increase incidence of cramping or injury during pre-season college football training: I [abstract]. Med Sci Sports Exerc, 31, S355.

Kristiansen M., Levy-Milne R., Barr S., \& Flint A. (2005). Dietary supplement use by varsity athletes at a canadian university. International Journal of Sport Nutrition and Exercise Metabolism, 15, 195-210. 
Krumbach C.J., Ellis D.R., \& Driskell J.A. (1999). A report of vitamin and mineral supplement use among university athletes in a division I institution. Int J Sport Nutr, $9,416-425$.

Kruskall L.J., \& Johnson L.J. (2001). Percieved benefits, sources of information and patterns of current and past supplement usage reported by male and female collegiate athletes. J Am Diet Assoc, 101 (S), A45.

Kuehl K., Goldber L., \& Elliot D. (1998). Renal insufficiency after creatine supplementation in a college football athlete [abstract]. Med Sci Sports Exerc, 30, S235.

LaBotz M., \& Smith B.W. (1999). Creatine supplement use in an NCAA division I athletic program. Clinical Journal of Sports Medicine, 9, 167-169.

Lambert M.I. et al. (1993). Failure of commercial oral amino acid supplements to increase serum growth hormone concentrations in male body builders. Int J Sport Nutr, 3, 290.

Lemon P.R.W. (1991). Protein and amino acid needs of the strength athlete. Int J Sport Nutr, 1, 127. 
Lemon P.W. (2000). Beyond the zone: Protein needs of active individuals. J Am Coll Nutr, 19(5 suppl), 513S-521S.

Lemon P.W., Tarnopolsky M.A., \& MacDougal J.D. et al. (1992). Protein requirements and muscle mass/strength changes during intensive training in novice bodybuilders. J Appl Physiol, 73(2), 767-775.

Lemon, P.W. (1998). Effects of exercise on dietary protein requirements. International Journal of Sport Nutrition, 8, 426-447.

Ma Y., Olendzki B., Chiriboga D., Hebert J., Li Y., Li W., Campbell M., Gendreau K., Ockene I. (2005). Association between dietary carbohydrates and body weight. American Journal of Epidemiology 161(4), 359-367.

Makowske M. \& Feinman R. (2005). Nutrition education: a questionnaire for assessment and teaching. Nutrition Journal, 4(1), 2

Madsen K., MacLean D., Biens B., \& Christensen D. (1996). Effects of glucose, glucose plus branched chain amino acids, or placebo on bike performance over $100 \mathrm{~km} . J$ Appl Physiol, 81(6), 2644-2650. 
Maughan R., \& Sadler D. (1983). The effects of oral administration of salts of aspartic acid on the metabolic response to prolonged exhausting exercise in man. Int J Sprots Med, 4(2), 119-123.

Max S.R. (1990). Glucocorticoid-mediated induction of glutamine syntehtase in skeletal muscle. Med Sci Sports Exerc, 22, 325-330.

McKenna M., Morton J., Selig S.E., \& Snow R.J. (1999). Creatine supplementation increases muscle total creatine but not maximal intermittent exercise performance. Journal of Applied Physiology, 87, 2244-2252.

McKinley Health Center. (2007). Ergogenic aids: Nutritional supplements for athletes. Retrieved 09/20, 2007, from http://www.mckinley.uiuc.edu/Handouts/ergogenic_aids.html Metzl J., Small E., Levine S., \& Gershel J. (2001). Creatine use among young athletes. Pediatrics, 108(2), 421.

Mihic S., MacDonald J.R., McKenzie S., \& et al. (2000). Acute creatine loading increases fat-free mass, but does not affect blood pressure, plasma creatinine, or CK activity in men and women. Med Sci Sports Exerc, 32, 291-296. 
Morey S. (1999). ACSM revises guidelines for exercise to maintain fitness. American Family Physician, 59(2).

Mowe M., Bosaeus I., Rasmussen H., Kondrup J., Unosson M., Rothenberg E., Irtun O. (2008). Insufficient nutritional knowledge among health care workers?. Clinical Nutrition, 27(1), 196-202.

Nemet D., \& Eliakim A. (2007). Protein and amino acid supplementation in sport. International SportMed Journal, 8(1), 11-23.

Newberry H., Beerman K., Duncan S., McGuire H., Hillers V. (2001). Use of nonvitamin nonmineral dietary supplements among college students. J Am Coll Health, 50(123129)

Pearson D.R., Hamby D.G., \& Mayhew J.L. (1999). Effect of oral creatine monohydrate and creatine phosphate supplementation on maximal strength indices, body composition, and blood pressure. Journal of Strength and Conditioning Research, $13,3-9$.

Poortmans J.R., \& Francaux M. (2000). Adverse effects of creatine supplementation: Fact or fiction? Sports Medicine, 30, 155-170. 
Poortmans J.R., \& Francaux M. (1997). Long term oral creatine supplementation does not impair renal function in healthy athletes. Med Sci Sports Exerc, 31, 1108-1110.

Powers K., \& Howley E. (2006). Exercise physiology: Theory and applicationto fitness and performance (6th ed.)McGraw-Hill.

Preen D., Dawson B., Goodman C., \& et al. (2001). Effect of creatine loading on longterm sprint exercise performance and metabolism. Med Sci Sports Exerc, 33, 814821.

Pritchard N.R., \& Kalra P.A. (1998). Renal dysfunction accompanying oral creatine supplements. Lancet, 351, 1252-1253.

Radimer K., Bindeald B., Hughes J., Ervin B., \& Swanson C. (2004). Dietary supplement use by US adults: Data from the national health and nutrition examination survey, 1999-2000. Am J Epidemiol, 160, 339-349.

Rasmussen B.B., Tipton K.D., \& Miller S.L. et al. (2000). An oral essential amino acid carbohydrate supplement enhances muscle protein anabolism after resistance exercise. J Appl Physiol, 88, 386-392. 
Rasmussen C., Kreider R., Melton C. et al. (1999). Long term creatine supplementation during football training does not affect markers of renal stress [abstract]. J Strength Cond Res, 13, 431.

Ray T., Eck J., Covington L., Murphy B., Williams R., \& Knudtson J. (2001). Use of oral creatine as an ergogenic aid for increased sports performance: Perceptions of adolescent athletes. Southern Medical Journal, 94(6), 608.

Romer L.M., Barrington J.P., \& Jeukendrup A.E. (2001). Effects of oral creatine supplementation on high intesity, intermittent exercise performance in competitive squash players. Int J Sports Med, 22, 546-552.

Rosen O., Sundgot-Borgen J., \& Maehlkm. (1999). Supplement use and nutritional habits in norwegian elite athletes. Scandinavian Journal of Medicine and Science in Sports, 9, 28-35.

Rossouw F., Kruger P.E., \& Rossouw J. (2000). The effect of creatine monohydrate loading on maximal intermittent high intensity exercise and sport-specific strength in well trained power-lifters. Nutr Res, 20, 505-514. 
Roy B.D., Tarnopolsky M.A., \& MacDougall J.D. et al. (1997). Effect of glucose supplement timing on protein metabolism after resistance training. J Appl Physiol, 82, $1882-1888$.

Schroeder C., Potteiger J., Randall J., \& et al. (2001). The effects of creatine dietary supplementation on anterior compartment pressure in the lower leg during rest and following exercise. Clin J Sport Med, 11, 87-95.

Sheppard H.L., Raichada S.M., Kouri K.M., Stenson-Bar-Maor L., \& Branch J.D. (2000). Use of creatine and other supplements by members of civilian and military helath clubs: A cross-sectional survey. International Journal of Sport Nutrition and Exercise Metabolism, 10, 245-259.

Skare O.C., Skadberg O., \& Wisnes A.R. (2001). Creatine supplementation improves sprint performance in male sprinters. Scan J Med Sci Sports, 11, 96-102.

Snow R.J., McKenna M.J., Selig S.E., Kemp J., Stathis C.G., \& Zhao S. (1998). Effect of creatine supplementation on sprint exercise performance and muscle metabolism. Journal of Applied Physiology, 84, 1667-1673.

Sobal J., \& Marquart L.F. (1994). Vitamin/mineral supplement use among athletes: A review of literature. Int J Sport Nutr, 4, 320-334. 
Spark People (a). (2007). Aerobic exercise. Retrieved 09/22, 2007, from http://sparkpeople.com/resource/reference_aerobic.asp

Spark People (b). (2007). Fitness reference guid: Anaerobic exercise. Retrieved 09/22, 2007, from http://sparkpeople.com/resource/reference_anaerobic.asp

Springboard. (2004). The nutrition notebook: Protein and amino acids. Retrieved 10/13, 2007, from http://www.springboard4health.com/notebook/cat_proteins.html

Steenge G.R., Lambourne J., Casey A., \& et al. (1998). Stimulatory effect of insulin on creatine accumulation in human skeletal muscle. American Journal of Physiology, 275, E974-E979.

Stensrud T., Ingjer F., Holm H., \& Stromme S.B. (1992). L-tryptophan supplementation does not improve running performance. Int J Sports Med, 13(6), 481-485.

Stephens M. (2001). Ergogenic aids: Powders, pills, and potions to enhance performance. American Family Physician, 63(5), 842-843.

Strauss G., \& Michoces G. (1998). Jury still out on creatine use. USA Today, June 4, C1C2.

Stroud M., Holliman D., Bell D., Green A., Macdonald I., \& Greenhaff P. (1994). Effect of oral creatine supplementation on respiratory gas exchange and blood lactate 
accumulation during steady-state incremental treadmill exercise and recovery in man. Clinical Science, 87, 854-857.

Tarnopolsky M.A., Atkinson S.A., MacDougall J.D., et al. (1992). Evaluation of protein requirements for trained strength athletes. J Appl Physiol, 73(5), 1986-1995.

Tarnopolsky M. (2004). Protein requirements for endurance athletes. Nutrition, 20, 662668.

Thompson, C., Kemp G.J., Sanderson A.J., Dixon R.M., Styles P, Tayler D.J., et al. (1996). Effect of creatine on aerobic and anaerobic metabolism6 in skeletal muscle in swimmers. British Journal of Sports Medicine, 30, 222-225.

Trappe S., Costill D., Goodpaster B., Vukovich M., \& Fink W. (1994). The effects of L carnitine supplementation on performance during interval swimming. Int J Sport Med, 15, 181-185.

University of Iowa Hospitals \& Clinics. (2007). Ergogenic aids. Retrieved 09/22, 2007, from http://www.uihealthcare.com/topics/sportsmedicine/spor3329.html

Van Hall G., Raaymakers J., Saris W., \& Wagenmakers A. (1995). Ingestion of branched chain amino acids and tryptophan during sustained exercise in man: Failure to affect performance. J Physiol, 486(3), 789-794. 
Van Loon L.J.C., Saris W.H.M., Verhagen H., \& Wagenmakers A.J.M. (2000). Plasma insulin response after ingestion of different amino acid or protein mixtures with carbohydrate. Am J Clin Nutr, 72, 96-105.

Vandebuerie F., Vanden Eynde B., Vandenberghe K., \& Hespel P. (1998). Effect of creatine loading on endurance capacity and sprint power in cyclists. Inernational Journal of Sports Medicine, 19, 490-495.

Vandenborne K., Walter G., Ploutz-Synder L., et al. (1995). Energy-rich phosphates in slow and fast human skeletal muscle. American Journal of Physiology, 268, C869876.

Varnier M., Sarto P., Martines D., Lora L., Carmignoto F., Leese G., et al. (1994). Effect of infusing branched chain amino acid during incremental exercise with reduced muscle glycogen content. Eur J Appl Physiol, 69(1), 26-31.

Vermunt S., Pasman W., Schaafsma G., Kardinaal A. (2003). Effects of sugar intake on body weight: a review. Obesity Reviews, 4(2), 91-99.

Volek J.S., Duncan N.D., Mazzetti S.A., Staron R.S., Putukian M., Gomez A.L., et al. (1999). Performance and muscle fiber adaptations to creatine supplementation and 
heavy resistance training. Medicine and Science in sports and exercise, 31, 11471156.

Volek J.S., Kraemer W.J., Bush J.A., \& et al. (1996). Creatine supplementation: Its effect on human muscular performance and body composition. J Strength Cond Res, 10, 200-210.

Vukovich M., Costill D., \& Fink W. (1994). Carnitine supplementation: Effect on muscle carnitine and glycogen content during exercise. J Appl Physiol, 26(9), 1122-1129.

Walsh N., Blannin A., Robson P., \& Gleeson M. (1998). Glutamine, exercise and immune function: Links and possible mechanisms. Sports Med, 25, 177-191.

Wildman R., \& Medeiros D. (2000). Advanced human nutrition (1st ed.). Boca Rato, Florida: CRC Press.

William M.H. (1999). Nutrition for health, fitness, and sport (5th ed.). Dubuque, IA: WCB/McGraw-Hill.

Williams Melvin. (1998). The ergogenics edge (1st ed.). Champaign IL: Human Kinetics.

Williams M.H., Kreider R.B., \& Branch J.D. (Eds.). (1999). Creatine - the power supplement: What it is, how it works, when it helps. Champaign (IL): Human Kinetics. 
Zaragoza R., Renau-Piqueras J., Portoles M., Hernandez-Yago J., Jorda A., \& Grisolia S. (1987). Rats fed prolonged high protein diets show an increase in nitrogen metabolism and liver megamitochondria. Arch Biochem Biophys, 258, 426-435.

Zeigenfuss T.N., Lowery L.M., \& Lemon P.W.R. (1998). Acute fluid volume changes in men during three days of creatine supplementation. J Exerc Physiol, 1, 1-9.

Ziegenfuss T.N., Lemon P.W.R., Rogers M.R., et al. (1997). Acute creatine ingestion: Effects on muscle volum, anaerobic power, fluid volumes, and protein turnover [abstract]. Med Sci Sports Exerc, 29, S127. 